\title{
Effects of body condition score at calving on indicators of fat and protein mobilization of periparturient Holstein-Friesian cows
}

\author{
J. A. A. Pires, ${ }^{*}{ }^{1}$ C. Delavaud, ${ }^{*} \dagger$ Y. Faulconnier, ${ }^{*} \dagger$ D. Pomiès,${ }^{*} \dagger$ and $Y$. Chilliard ${ }^{*} \dagger$ \\ *INRA, UMR1213 Herbivores, F63122 Saint-Genès-Champanelle, France \\ †Clermont Université, VetAgro Sup, BP 10448, F-63000, Clermont-Ferrand, France
}

\begin{abstract}
The objective was to study the effects of body condition score (BCS) at calving on dairy performance, indicators of fat and protein mobilization, and metabolic and hormonal profiles during the periparturient period of Holstein-Friesian cows. Twenty-eight multiparous cows were classed according to their BCS (0 to 5 scale) before calving as low ( $\mathrm{BCS} \leq 2.5 ; \mathrm{n}=9)$, medium (2.75 $\leq \mathrm{BCS} \leq 3.5 ; \mathrm{n}=10)$, and high $(\mathrm{BCS} \geq 3.75 ; \mathrm{n}=9)$, corresponding to a mean of $2.33,3.13$, and 4.17 points of BCS, and preceding calving intervals of 362, 433, and $640 \mathrm{~d}$, respectively. Cows received the same diets based on preserved grass to allow ad libitum feed intake throughout the study, and lactation diet contained $30 \%$ of concentrate (dry-matter basis). Measurements and sampling were performed between wk -4 and 7 relative to calving. No significant effects were observed of BCS group on dry matter intake $(\mathrm{kg} / \mathrm{d})$, milk yield, BCS loss, plasma glucose, and insulin concentrations. The high-BCS group had the lowest postpartum energy balance and the greatest plasma concentrations of leptin prepartum, nonesterified fatty acids and $\beta$-hydroxybutyrate postpartum, insulin-like growth factor 1 , and milk fat content. Milk fat yield was greater for the high- than the low-BCS group (1,681 vs. 1,417 $\mathrm{g} / \mathrm{d})$. Low-BCS cows had the greatest concentration of medium-chain fatty acids (e.g., sum of 10:0 to 15:0, and 16:0), and the lowest concentration and secretion of preformed fatty acids (e.g., cis-9 18:1) in milk fat. Milk protein secretion was lowest in the low-BCS group, averaging 924, 1,051, and 1,009 g/d for low-, medium-, and high-BCS groups, respectively. Plasma 3-methylhistidine was greater in wk 1 and 2 postpartum compared with other time points, indicating mobilization of muscle protein. Plasma creatinine tended to be lower and the 3-methylhistidine: creatinine ratio was greater in low- compared with medium- and high-BCS cows, suggesting less muscle mass but more intense mobiliza-
\end{abstract}

Received March 13, 2013.

Accepted June 14, 2013.

${ }^{1}$ Corresponding author: jose.pires@clermont.inra.fr tion of muscle protein in lean cows. High-BCS cows were metabolically challenged during early lactation due to intense mobilization of body fat. Conversely, limited availability of body fat in low-BCS cows was associated with increased plasma indicators of body protein mobilization during the first weeks of lactation, and lower milk protein secretion. These results should be confirmed using an experimental approach where calving BCS variation would be controlled by design.

Key words: bovine, lactation, body reserve, mobilization

\section{INTRODUCTION}

The periparturient dairy cow experiences profound physiological and metabolic adaptations to support lactation, simultaneous with environmental challenges due to transitions of diet, housing, and social interactions. Physiological adjustments include short-term (homeostasis) and long-term (homeorhesis/teleophoresis) hormonal changes and altered tissue response to key hormones that lead to increased net lipolysis, enhanced utilization of mobilized FA by peripheral tissues and the mammary gland, and mobilization of the limited glucose and amino acid reserves (e.g., liver glycogen and muscle protein; Bell and Bauman, 1997; Chilliard, 1999). Furthermore, ruminants depend on gluconeogenesis as the major source of glucose, but the increase in hepatic glucose output during early lactation is insufficient to meet requirements, and other adjustments of nutrient partitioning must take place to cope with this shortfall (Doepel et al., 2009), namely by the establishment of insulin resistance in peripheral tissues (Bell and Bauman, 1997).

Fat and labile protein reserves are mobilized during early lactation, but the ability to use body protein is limited in quantity and duration. For instance, estimates have ranged from 10 to $90 \mathrm{~kg}$ of fat, and up to $24 \mathrm{~kg}$ of protein (Komaragiri and Erdman, 1997; Chilliard, 1999; Chibisa et al., 2008). No further protein mobilization occurred after 5 wk of lactation, whereas utilization of body fat continued until at least $12 \mathrm{wk}$ postpartum (Komaragiri and Erdman, 1997). Continuous genetic selection with emphasis on milk yield has 
led to chronic low BCS in modern dairy cows, especially in grass-based systems, and to a decline in reproductive performance, probably due to prioritization of nutrient partition toward milk secretion (Chagas et al., 2007; Roche et al., 2009). Limited information exists on the mobilization of body reserves in cows with extreme BCS because most studies focus on animals in the medium range, and receiving conventional highenergy lactation diets ad libitum (Broster and Broster, 1998; Roche et al., 2009). Furthermore, correlation between BCS and body fat may be weaker at the lower end of the BCS scale, and it has been speculated that BCS loss in lean cows may correspond to muscle mobilization (Chagas et al., 2007). Additionally, cows may undergo extended lactations when insemination is voluntarily delayed to avoid periods of extreme negative energy balance (EBAL), as a result of reproductive failure, or to group calvings in a defined season (Kolver et al., 2007; Kay et al., 2009). Animals that experience extended lactations may increase their BCS over time (Kolver et al., 2007), especially if rations are not solely composed of pasture. Semi-mountain dairy production systems in central France are mostly grass based, and include a fall/winter indoor period and a spring/summer grazing season. Despite year-round milking, calvings are generally concentrated in the fall and winter seasons. Cows that are not inseminated or do not become pregnant during the breeding period may be maintained in extended lactations. Therefore, the diversity of intercalving intervals within a herd is likely to lead to BCS heterogeneity. The objective of this study was to assess the effects of BCS at calving on the adaptability of dairy cows to a moderate-energy diet based on preserved grass. Namely, to study how different calving BCS that resulted at least in part from variable calving intervals relate to dairy performance, changes in BW and BCS, plasma indicators of fat and protein mobilization, and overall metabolic and hormonal profile during the periparturient period. We expected that cows calving with high BCS would be metabolically challenged during early lactation due to mobilization of body fat. Conversely, we hypothesized that utilization of body reserves would be altered in low-BCS cows due to the limited availability of body fat, and that mobilization of body protein during the first weeks of lactation would be more intense in these animals.

\section{MATERIALS AND METHODS}

\section{Animals, Diets, and Housing}

The experiment was conducted in the Orcival farm of the Institut National de la Recherche Agronomique
(INRA), located in a semi-mountain grassland area (1,000 $\mathrm{m}$ of altitude) in the Auvergne region (Puy-deDôme, France). Twenty-eight multiparous HolsteinFriesian cows were studied from 4 wk before expected calving until 7 wk postpartum. Cows were classed according to their BCS before calving as low (BCS $\leq 2.5$; $\mathrm{n}=9)$, medium $(2.75 \leq \mathrm{BCS} \leq 3.5 ; \mathrm{n}=10)$, and high (BCS $\geq 3.75 ; \mathrm{n}=9$ ) using the French notation scale of 0 to 5 (Table 1; Bazin et al., 1984). Different BCS were due to differences in previous intercalving intervals (Table 1). In the North-American 1 to 5 scale (Edmonson et al., 1989), low-, medium-, and high-BCS groups would correspond to $\mathrm{BCS} \leq 3.0,3.2 \leq \mathrm{BCS} \leq 3.8$, and BCS $\geq 4.0$, respectively, assuming a linear relationship between scoring systems. Cows received identical diets to allow ad libitum feed intake throughout the study (10\% refusals). Diet ingredient, nutrient, and FA composition are presented in Table 2 . The far-off dry period diet was mixed forage composed of $75 \%$ grass silage and $25 \%$ hay (DM basis) from permanent semi-mountain grasslands rich in Dactylis glomerata (orchardgrass). Starting $3 \mathrm{wk}$ before the expected calving date, the forage mixture was top-dressed with $2 \mathrm{~kg}$ of the lactation concentrate. Lactation TMR was (DM basis) $46.5 \%$ grass silage, $22 \%$ hay, $30 \%$ concentrate, and $1.5 \%$ of a mineral and a vitamin premix. The lactation diet was initially formulated to meet $85 \%$ of energy and $100 \%$ of protein requirements to produce $32 \mathrm{~kg} / \mathrm{d}$ of milk based on table values (INRA, 2007). Cows were housed in a freestall barn with individual feed bunks equipped with automatic gates, were milked at 0630 and $1600 \mathrm{~h}$, and had free access to water throughout the study.

\section{Sampling and Analyses}

Blood samples were collected from the jugular vein after morning milking and before feeding at wk $-4,-2$, $1,2,3,5$, and 7 relative to calving date, corresponding to $-28,-14,4,11,18,32$, and 46 DIM, respectively (SD $=7$ DIM prepartum and 1 DIM postpartum). Blood samples were drawn into evacuated tubes containing either EDTA $(1.95 \mathrm{mg} / \mathrm{mL})$ or Li-heparin (10 $\mathrm{IU} / \mathrm{mL}$; Terumo Europe NV, Leuven, Belgium). Plasma was separated by centrifugation at $1,400 \times g$ for 15 min at $4^{\circ} \mathrm{C}$ and frozen at $-20^{\circ} \mathrm{C}$. Plasma (EDTA) was analyzed for glucose, NEFA, BHBA using enzymatic methods, and for insulin and leptin using RIA, as previously described (Delavaud et al., 2002; Lerch et al., 2012a). Plasma IGF1 concentration was determined by RIA (IGF-I RIA-CT; Mediagnost GmbH, Reutlingen, Germany) validated for the bovine. Heparinized plasma was analyzed for 3-methylhistidine (3-MH) by HPLC (Adechian et al., 2012), and creatinine was quantified in selected samples (wk -4, 1, 2, and 7) using an auto- 
Table 1. Allotment of dairy cows by BCS group and parity ${ }^{1}$

\begin{tabular}{|c|c|c|c|c|c|c|c|}
\hline Item & \multicolumn{2}{|c|}{ Parity $^{2}$} & \multicolumn{3}{|c|}{ BCS group } & \multicolumn{2}{|c|}{$P$-value } \\
\hline $\mathrm{n}$ & 17 & 11 & 9 & 10 & 9 & - & - \\
\hline Lactation number ${ }^{2}$ & - & - & $2.78 \pm 0.48$ & $3.1 \pm 0.46$ & $2.67 \pm 0.48$ & - & 0.80 \\
\hline Age at calving ${ }^{2}(\mathrm{mo})$ & $41.0 \pm 1.49$ & $78.2 \pm 5.97$ & $60.6 \pm 7.30$ & $54.2 \pm 7.70$ & $51.4 \pm 7.70$ & $<0.001$ & 0.68 \\
\hline Calving interval $^{4}(\mathrm{~d})$ & $416 \pm 32$ & $572 \pm 40$ & $640 \pm 51^{\mathrm{a}}$ & $433 \pm 24^{\mathrm{b}}$ & $362 \pm 7^{\mathrm{b}}$ & $<0.01$ & $<0.001$ \\
\hline
\end{tabular}

${ }^{\mathrm{a}-\mathrm{c}}$ Means within a row with different superscript letters differ $(P<0.05)$.

${ }^{1}$ Values are $\mathrm{LSM} \pm \mathrm{SEM}$.

${ }^{2}$ During the current lactation.

${ }^{3}$ Scale from $0=$ thin to $5=$ fat, recorded during the last 2 weeks of gestation.

${ }^{4}$ Prior to the current lactation.

matic analyzer (Jaffe method; Modular P800 analyzer; Roche Diagnostics, Mannheim, Germany). Intra-and interassay coefficients of variation were 1.8 and $2.8 \%$ for glucose, 2.8 and $7.7 \%$ for NEFA, 1.8 and $3.8 \%$ for BHBA, 0.7 and $2.3 \%$ for creatinine, 9 and $9.6 \%$ for insulin, 5.8 and $11.6 \%$ for leptin, and 4.6 and $15.0 \%$ for IGF-1, respectively.
Feed and refusals were weighted $4 \mathrm{~d}$ per wk, and subsamples were collected weekly and pooled monthly to determine the DM content and calculate DMI. Forage and concentrate samples were collected monthly, stored at $-20^{\circ} \mathrm{C}$, and analyzed for nutrient composition, as previously described (Lerch et al., 2012a). Diet energy and protein truly digestible in the small intestine (PDI)

Table 2. Diet ingredient, nutrient, and FA composition

\begin{tabular}{|c|c|c|c|}
\hline Item & $\begin{array}{c}\text { Far-off } \\
\text { dry period }{ }^{1}\end{array}$ & $\begin{array}{l}\text { Close-up } \\
\text { dry period }\end{array}$ & Lactation \\
\hline \multicolumn{4}{|l|}{ Ingredient ( $\%$ of DM) } \\
\hline Grass silage $^{3}$ & 75 & 66 & 46.5 \\
\hline $\mathrm{Hay}^{3}$ & 25 & 22 & 22 \\
\hline Concentrate $^{4}$ & - & 12 & 30 \\
\hline Mineral and vitamin $\operatorname{mix}^{5}$ & - & - & 1.5 \\
\hline \multicolumn{4}{|c|}{ Nutrient composition (\% of DM) } \\
\hline Net energy (MJ/kg of DM) & 5.7 & 5.9 & 6.1 \\
\hline $\mathrm{CP}$ & 14.1 & 14.6 & 15.4 \\
\hline $\mathrm{PDI}^{6}$ & 7.4 & 7.8 & 8.3 \\
\hline $\mathrm{NDF}$ & 59.6 & 56.6 & 52.0 \\
\hline $\mathrm{ADF}$ & 35.8 & 32.7 & 28 \\
\hline Fat & 4.5 & 4.4 & 4.1 \\
\hline Ash & 9.9 & 9.5 & 9.0 \\
\hline \multicolumn{4}{|l|}{ FA composition ( $\mathrm{g} / 100 \mathrm{~g}$ of $\mathrm{FA})$} \\
\hline C16:0 & 17.35 & 17.05 & 16.61 \\
\hline C18:0 & 1.92 & 1.90 & 1.86 \\
\hline cis-11 C18:1 & 0.45 & 0.86 & 1.50 \\
\hline cis-9 C18:1 & 4.57 & 8.05 & 13.34 \\
\hline C18:2n-6 & 23.86 & 25.44 & 27.84 \\
\hline C18:3n-3 & 45.56 & 40.83 & 33.64 \\
\hline Other & 6.28 & 5.86 & 5.22 \\
\hline
\end{tabular}

${ }^{1}$ From drying-off to 3 wk before expected calving.

${ }^{2}$ Introduced 3 wk before expected calving; duration was $3.4 \pm 1.2$ wk.

${ }^{3}$ Permanent semi-mountain grasslands rich in Dactylis glomerata (orchardgrass).

${ }^{4}$ Concentrate contained $7 \mathrm{MJ}$ and $104 \mathrm{~g}$ of protein truly digestible in the small intestine $/ \mathrm{kg}$ of DM, $18.6 \% \mathrm{CP}$, $34.1 \% \mathrm{NDF}$, and $3.2 \%$ fat; composed of $24 \%$ wheat bran, $15 \%$ dehydrated distillers grains by-product $(<7 \%$ starch), $15 \%$ triticale, $12 \%$ wheat, $10 \%$ beet pulp, $10 \%$ dehydrated distillers barley rootlets, $6 \%$ corn cobs, $2 \%$ sunflower meal, $2 \%$ rapeseed meal, $2 \%$ sugar cane molasses, $1 \%$ rapeseed grains, $0.5 \%$ wheat shorts, $0.25 \%$ calcium carbonate, and $0.25 \%$ sodium chloride (on a DM basis).

${ }^{5}$ Mineral and a vitamin mix contained $3 \% \mathrm{P}, 22 \% \mathrm{Ca}, 5 \% \mathrm{Mg}, 2.5 \% \mathrm{Na}, 1 \% \mathrm{~S}, 375,000 \mathrm{IU}$ of vitamin A $/ \mathrm{kg}$, $110,000 \mathrm{IU}$ of vitamin $\mathrm{D}_{3} / \mathrm{kg}, 1,500 \mathrm{IU}$ of vitamin $\mathrm{E} / \mathrm{kg}, 1 \mathrm{~g}$ of $\mathrm{Cu} / \mathrm{kg}, 6 \mathrm{~g}$ of $\mathrm{Zn} / \mathrm{kg}, 2.5 \mathrm{~g}$ of Mn/ $\mathrm{kg}, 100 \mathrm{mg}$ of $\mathrm{I} / \mathrm{kg}$, $40 \mathrm{mg}$ of $\mathrm{Co} / \mathrm{kg}$, and $24 \mathrm{mg}$ of Se/kg (Galaphos Midi ensil; CCPA, Aurillac, France).

${ }^{6}$ Protein truly digestible in the small intestine (INRA, 2007). 
Table 3. Effects of BCS at calving and parity on changes in BW and BCS, intake, and nutritional balance of periparturient Holstein-Friesian cows

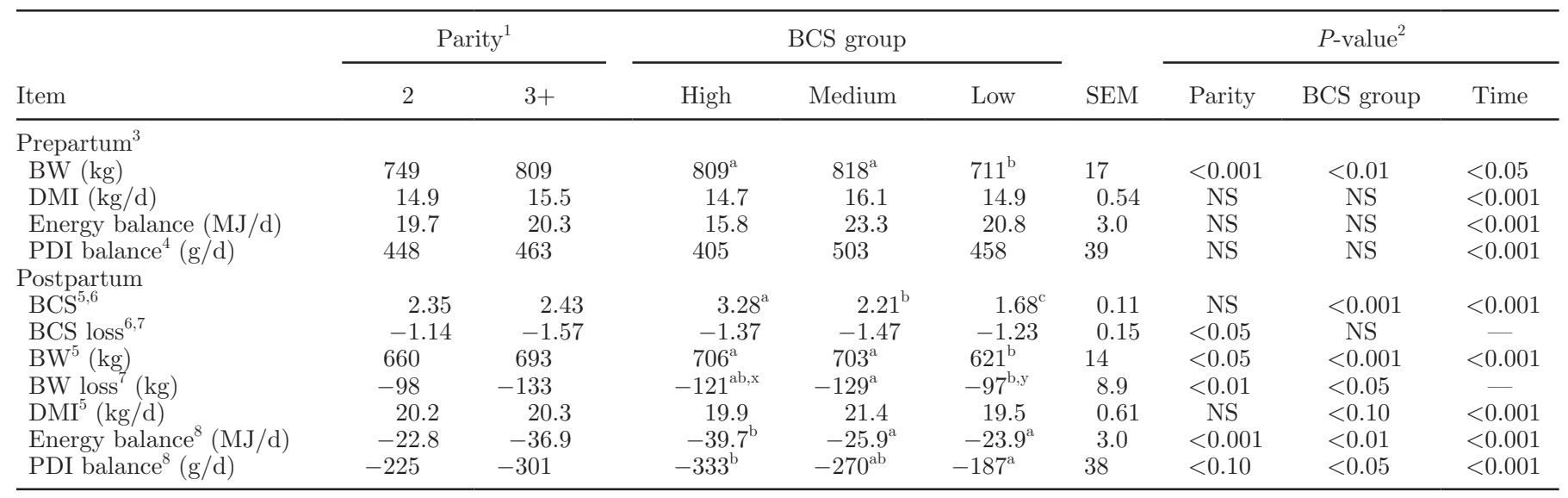

${ }^{\mathrm{a}-\mathrm{c}}$ Means within a row with different superscript letters differ $(P<0.05)$.

${ }^{\mathrm{x}, \mathrm{y}}$ Means within a row with different superscript letters tend to differ $(P=0.06)$.

${ }^{1}$ Parity during the current lactation.

${ }^{2}$ Parity by time interaction was nonsignificant for all variables; BCS group by time interaction was nonsignificant for all variables except for postpartum BW $(P<0.05)$.

${ }^{3}$ Weeks 3,2 , and 1 prepartum.

${ }^{4} \mathrm{PDI}=$ protein truly digestible in the small intestine.

${ }^{5}$ Weeks 1 to 7 postpartum.

${ }^{6}$ Scale from $0=$ thin to $5=$ fat.

${ }^{7}$ Change from prepartum until wk 7 postpartum.

${ }^{8}$ Calculated from wk 2 to 7 postpartum.

content and energy and PDI balances were calculated according to the INRA (2007) system (Tables 2 and $3)$. Milk yield was recorded daily, and milk samples were collected at 4 consecutive milkings each week and analyzed for components by near-infrared spectrometry (Lerch et al., 2012a). Milk FA composition was determined by gas-liquid chromatography in pooled samples from morning and evening milking collected on the same day of blood drawing, as previously described (Lerch et al., 2012b). Secretion of individual milk FA was calculated according to Glasser et al. (2007). Cows were weighed weekly and BCS (Bazin et al., 1984) was recorded once during the 2 wk before expected calving and weekly thereafter. All procedures were conducted in accordance with the French guidelines for experimental animal use.

\section{Calculations and Statistical Analyses}

Data were analyzed using PROC MIXED of SAS (version 9.1; SAS Institute Inc., Cary, NC) with repeated measures. The statistical model included the fixed effects of BCS group, parity (second or third and greater), time, and 2-way interactions with time, cow as a random effect, and Kenward-Rogers adjustment for calculation of denominator degrees of freedom.
Variance-covariance structures [spatial power, [AR(1)], compound symmetric (CS)] and heterogeneous variances were selected depending on which yielded the best fit according to the Schwarz Bayesian criterion. Nonsignificant 2-way interactions were removed from the model for all variables except for milk FA composition and secretion, for which the full statistical model and spatial power variance-covariance structure were kept.

Logarithmic transformation was used whenever needed to comply with the assumptions of normality and homoscedasticity of the residuals. When transformation was needed, least squares means and standard error of the mean were estimated from untransformed values, and $P$-values reflect statistical analyses of transformed data. Values reported are least squares means and standard error of the mean, unless otherwise stated. The significance level was predefined at $P \leq 0.05$, and trends toward significance were considered at $0.05<P$ $\leq 0.10$. The SLICE option was used to compare treatment differences at individual time points when treatment or treatment by time interaction was significant. A contrast comparing plasma creatinine, $3-\mathrm{MH}$ and the ratio 3-MH:creatinine of low- versus medium- and highBCS groups was used to test the hypothesis of different muscle mobilization in lean cows. 


\section{RESULTS}

\section{BCS, Weight, and Intake}

The BCS before calving was 2.33, 3.13, and $4.17 \pm$ 0.10 , and the preceding calving interval was 362,433 , and $640 \mathrm{~d}$ for low-, medium-, and high-BCS groups, respectively $(P<0.001$; Table 1$)$. All the cows in this study were multiparous and 17 out of the 28 were starting their second lactation. The number of lactations did not differ among the 3 BCS groups (Table 1). The differences in postpartum BCS were consistent with calving BCS classes $(P<0.001)$, but the BCS change during the first 7 wk of lactation did not differ across BCS groups (Table 3; Figure 1). Body weight was lowest for the low-BCS group throughout the study $(P$ $<0.01$ ), but it did not differ between medium- and high-BCS groups (Table 3; Figure 1). Body weight loss during the first 7 wk of lactation did not differ between high- and medium-BCS groups, but the low-BCS group lost less BW than the medium-BCS group $(P<0.05$;
Table 3 ) and tended to lose less BW than the high-BCS group $(P<0.10$; Table 3$)$.

Prepartum DMI decreased gradually during the last 3 wk of gestation. It was $16.0,15.4$, and $14.3 \mathrm{~kg} / \mathrm{d}(P<$ $0.001)$ at $\mathrm{wk}-3,-2$, and -1 , respectively, and did not differ among BCS classes (Table 3; Figure 1). Overall, DMI increased significantly during the first $3 \mathrm{wk}$ postpartum, and tended to be greater in the medium-BCS group, averaging 19.5, 21.4, and $19.9 \mathrm{~kg} / \mathrm{d}$ during the first 7 wk of lactation for low-, medium-, and high-BCS group, respectively, and no BCS group by time interaction was observed (Table 3; Figure 1).

Cows in second lactation had experienced a shorter prior calving interval (416 vs. $572 \mathrm{~d} ; P<0.01$; Table 1 ), presented lower prepartum BCS (2.90 vs. 3.68 points; $P$ $<0.001$; Table 1) and BW (749 vs. $809 \mathrm{~kg} ; P<0.001$; Table 3 ), and lost less BCS (1.14 vs. 1.57 points; $P<$ 0.05; Table 3) and BW (98 vs. $133 \mathrm{~kg} ; P<0.01$; Table 3 ) during the first 7 wk of lactation, compared with cows in the third-and-greater lactation.
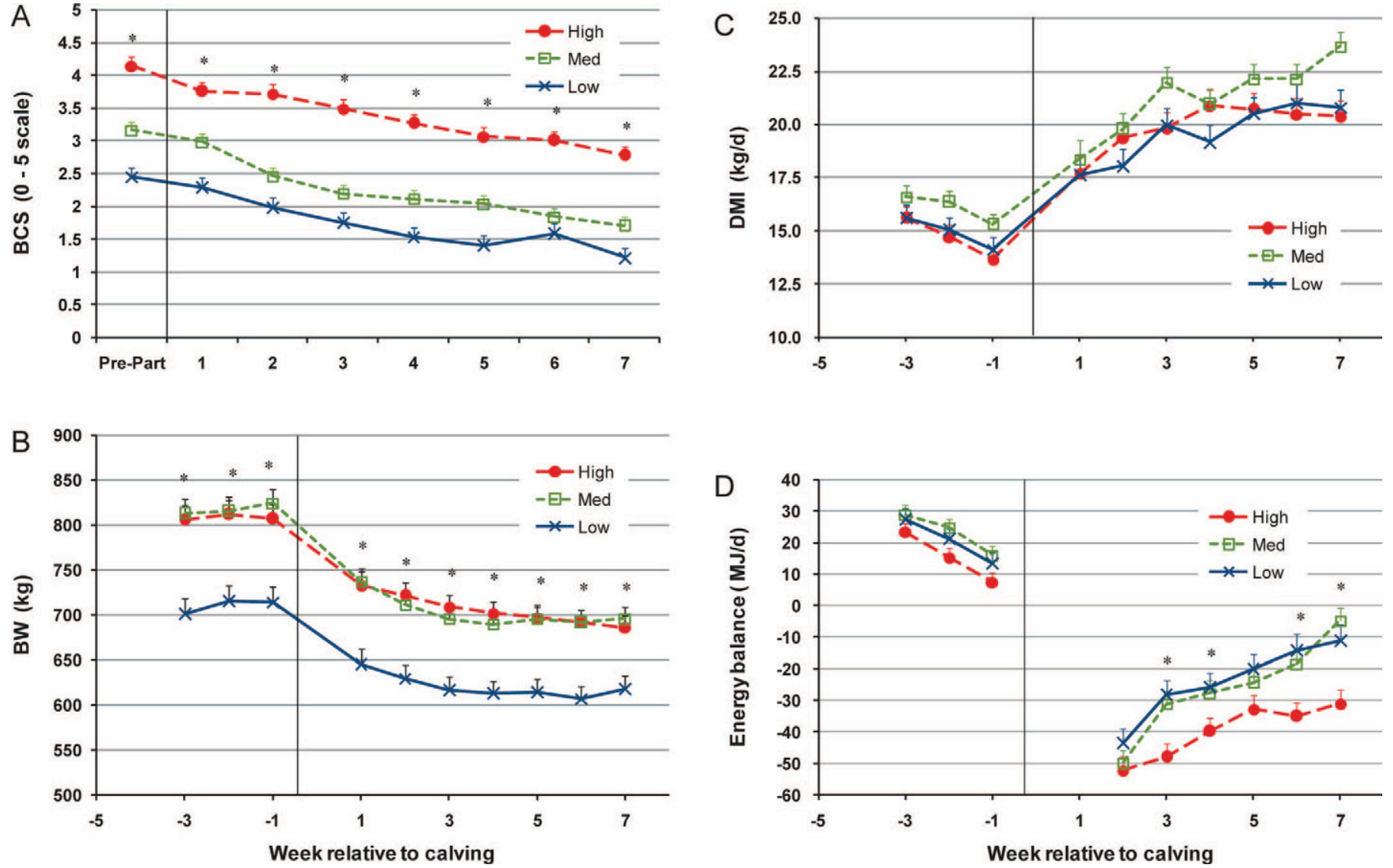

Figure 1. Effects of BCS at calving on changes in body condition (A), weight (B), DMI (C), and energy balance (D) of periparturient Holstein-Friesian cows. The BCS before calving was 2.33, 3.13, and 4.17 on a 6-point (0 to 5) scale for low-, medium (Med)-, and high-BCS groups, respectively. $P$-values of significant fixed effects in the statistical models are presented in Table 3 . Significant BCS group differences within a week are indicated by * (in panel A: $P<0.01$; panel B: $P<0.001$; panel D: $P \leq 0.05$ ). Error bars indicate standard error of the mean. Color version available in the online PDF. 


\section{Milk Production and Milk Composition}

Milk yield was 33.4, 36.4, and $35.2 \mathrm{~kg} / \mathrm{d}$ for low-, medium-, and high-BCS groups, respectively (Table 4; Figure 2) but did not differ statistically. Fat-corrected milk yield tended to differ across BCS groups (Table 4). Milk fat content was greatest for the high-BCS group $(P<0.01)$ and did not differ between medium- and low-BCS groups (Table 4; Figure 2). Milk fat yield was greater for the high- than low-BCS group (1,681 vs. $1,417 \mathrm{~g} / \mathrm{d} ; P<0.05$; Table 4; Figure 2). Milk protein yield was lowest for the low-BCS group $(P<0.05$; Table 4; Figure 2), averaging 924, 1,051, and 1,009 g/d for low-, medium-, and high-BCS groups, respectively.

Milk yield tended to be lower, and milk fat content, fat yield, and FCM yield were lower for second- compared with third-and-greater-lactation cows $(P<0.05$; Table 4). No parity effects were observed on milk protein content and yield.

\section{Energy and Protein Balance}

Prepartum EBAL remained positive but decreased from $26.7 \mathrm{MJ} / \mathrm{d}$ at wk -3 to 20.6 and $12.4 \mathrm{MJ} / \mathrm{d}$ at wk -2 and $-1(P<0.001)$, respectively, and did not differ among BCS groups (Table 3; Figure 1). Postpartum EBAL was lowest $(P<0.01)$ for the high-BCS group, did not differ between low- and medium-BCS groups (Table 3; Figure 1), and averaged $-23.9,-25.9$, and $-39.7 \mathrm{MJ} / \mathrm{d}$ for low-, medium-, and high-BCS groups, respectively (Table 3; Figure 1). None of the 3 BCS groups reached positive EBAL by wk 7 postpartum, when it was $-11.0,-4.6$, and $-30.9 \mathrm{MJ} / \mathrm{d}$ for low-, medium-, and high-BCS groups, respectively (Figure 1).

Prepartum PDI balance did not differ across BCS groups and decreased from 539 to $363 \mathrm{~g} / \mathrm{d}$ at wk -3 and -1 , respectively $(P<0.001)$. Overall, PDI balance was negative during the first 7 wk postpartum, averaging $-596,-350,-254,-178,-131$, and -72 $\mathrm{g} / \mathrm{d}$ at wk 2 to $7(P<0.001)$, respectively. Postpartum PDI balance was lower for the high- compared with the low-BCS group $(P<0.05)$, but the medium-BCS group did not differ from the other 2 BCS classes (Table 3 ). Postpartum EBAL was lower ( -36.9 vs. $-22.8 \mathrm{MJ} / \mathrm{d}$; $P<0.001)$ and PDI balance tended to be lower (301 vs. $-225 \mathrm{~g} / \mathrm{d} ; P=0.10$; Table 3 ) for third-and-greatercompared with second-lactation cows.

\section{Plasma Metabolites and Hormones}

Plasma Metabolites. Plasma glucose concentration did not differ across BCS groups (Table 5; Figure 3). Plasma NEFA concentrations were greatest for the high-BCS group $(P<0.05$; Table 5$)$, with significant effects postpartum (Figure 3). At wk 1 and 2, plasma NEFA was lowest for the low-BCS group, and the medium-BCS group did not differ from the high-BCS group. At wk 3 and 5, the medium-BCS group did not differ from the other 2. At wk 7, plasma NEFA was greatest in the high-BCS group (Figure 3). The highBCS group presented the greatest BHBA at wk 5 and 7 postpartum (Figure 3), leading to a BCS group by time interaction (Table 5).

Plasma NEFA $(P<0.01)$ and BHBA $(P<0.05)$ concentrations were greater in third-and-greater- than second-lactation cows (Table 5). A parity by week interaction was observed for BHBA concentration because effects were significant only at wk 2,3 , and 7 postpartum (data not shown). A parity by week interaction was observed for plasma glucose concentration because third-and-greater-lactation cows had greater glucose concentrations at wk -4 (70.2 vs. 66.8 ; $P<$ $0.05)$, but glucose concentration tended to be lower postpartum $(55.9$ vs. $59.4 \mathrm{mg} / \mathrm{dL} ; P=0.07)$ than in second-lactation cows (data not shown).

Table 4. Effects of BCS at calving and parity on milk production and composition of early-lactation Holstein-Friesian cows

\begin{tabular}{|c|c|c|c|c|c|c|c|c|c|c|}
\hline \multirow[b]{2}{*}{ Item } & \multicolumn{2}{|c|}{ Parity $^{1}$} & \multicolumn{3}{|c|}{ BCS group } & \multirow[b]{2}{*}{ SEM } & \multicolumn{4}{|c|}{$P$-value ${ }^{2}$} \\
\hline & 2 & $3+$ & High & Medium & Low & & Parity & $\begin{array}{l}\text { BCS } \\
\text { group }\end{array}$ & Time & $\begin{array}{l}\text { BCS group } \\
\times \text { time }\end{array}$ \\
\hline Milk yield ${ }^{3}(\mathrm{~kg} / \mathrm{d})$ & 33.8 & 36.2 & 35.2 & 36.4 & 33.4 & 1.25 & $<0.10$ & NS & $<0.001$ & NS \\
\hline $4 \% \mathrm{FCM}^{4}(\mathrm{~kg} / \mathrm{d})$ & 35.2 & 39.9 & 39.8 & 37.7 & 35.2 & 1.5 & $<0.01$ & $<0.10$ & $<0.001$ & $<0.10$ \\
\hline Milk fat ${ }^{4}(\%)$ & 4.04 & 4.41 & $4.59^{\mathrm{a}}$ & $4.00^{\mathrm{b}}$ & $4.08^{\mathrm{b}}$ & 0.13 & $<0.05$ & $<0.01$ & $<0.001$ & $<0.10$ \\
\hline Milk fat yield ${ }^{4}(\mathrm{~g} / \mathrm{d})$ & 1,414 & 1,657 & $1,681^{\mathrm{a}}$ & $1,509^{\mathrm{ab}}$ & $1,417^{\mathrm{b}}$ & 72 & 0.01 & $<0.05$ & $<0.001$ & 0.01 \\
\hline Milk protein ${ }^{4}(\%)$ & 2.78 & 2.71 & 2.76 & 2.80 & 2.68 & 0.05 & NS & NS & $<0.001$ & NS \\
\hline Milk protein yield ${ }^{4}(\mathrm{~g} / \mathrm{d})$ & 974 & 1,014 & $1,009^{\mathrm{a}}$ & $1,051^{\mathrm{a}}$ & $924^{\mathrm{b}}$ & 34 & NS & $<0.05$ & $<0.001$ & $<0.05$ \\
\hline $\log _{10} \mathrm{SCC}^{4}$ & 4.46 & 4.56 & 4.41 & 4.69 & 4.43 & 0.12 & NS & NS & NS & NS \\
\hline
\end{tabular}

\footnotetext{
${ }^{\mathrm{a}, \mathrm{b}}$ Means within a row with different superscript letters differ $(P<0.05)$.

${ }^{1}$ Parity during the current lactation.

${ }^{2}$ Parity by time interaction was nonsignificant for all variables.

${ }^{3}$ Weeks 1 to 7 of lactation.

${ }^{4}$ Weeks 2 to 7 of lactation.
} 
A

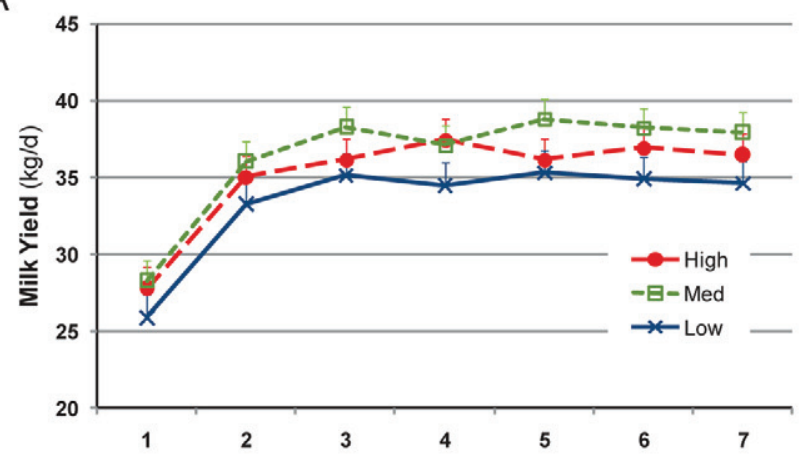

C

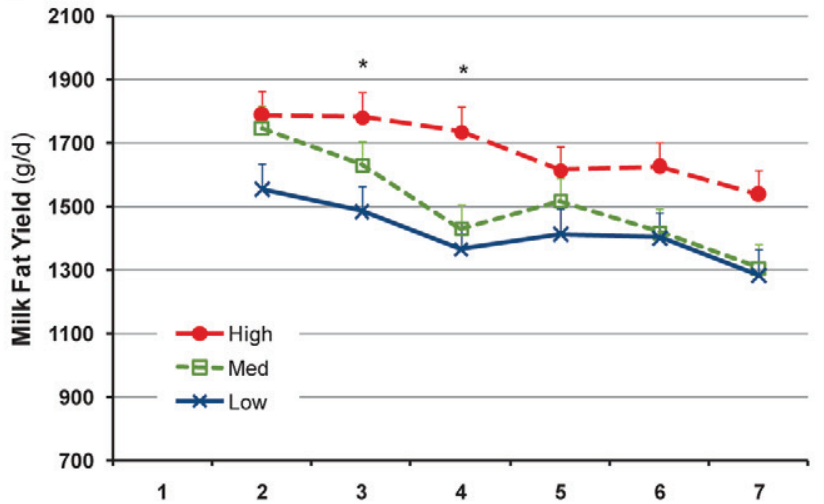

E

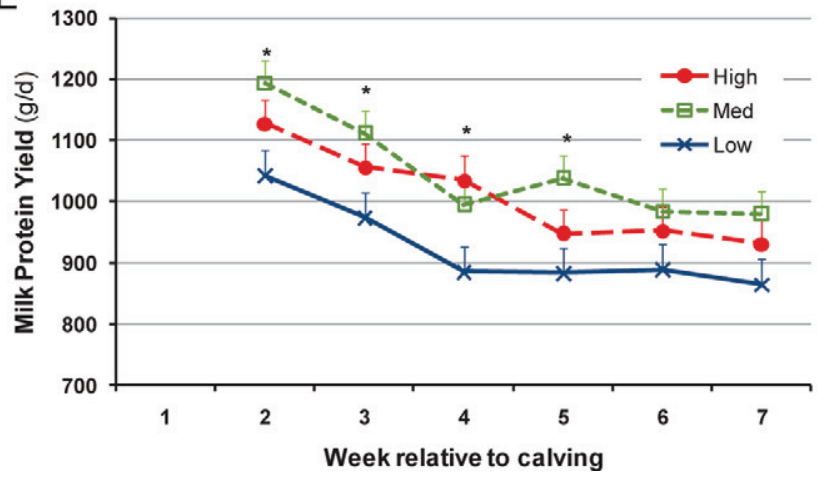

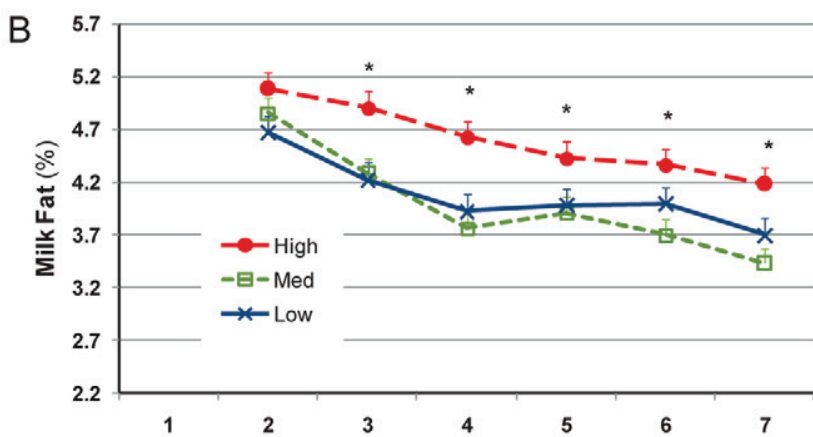

D

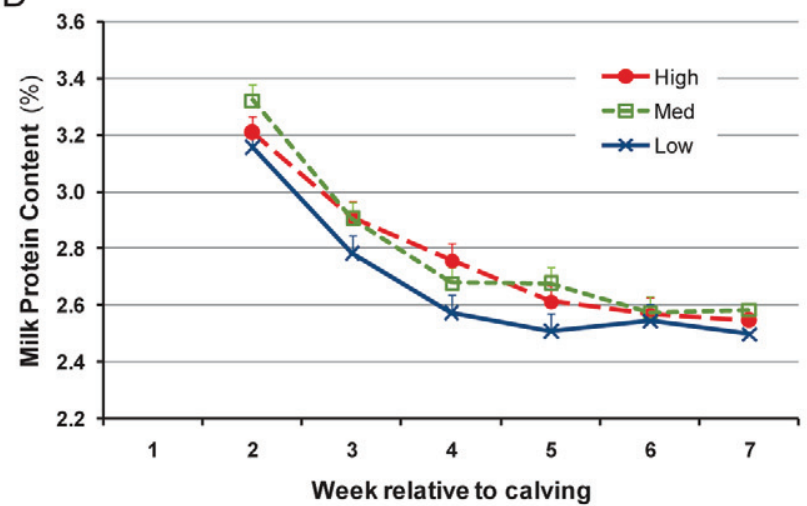

Figure 2. Effects of BCS at calving on milk production and composition of early-lactation dairy cows. The BCS before calving was 2.33, 3.13 , and 4.17 on a 6 -point ( 0 to 5 ) scale for low-, medium (Med)-, and high-BCS groups, respectively. $P$-values of significant fixed effects in the statistical models are presented in Table 4. Significant BCS group differences within a week are indicated by $*$ (panels B, C, and E: $P<0.05$ ). Error bars indicate standard error of the mean. Color version available in the online PDF.

Plasma Indicators of Muscle Mobilization. Plasma 3-MH concentrations increased postpartum but decreased quickly (Figure 4). Plasma 3-MH was greater in wk 1 and 2 postpartum compared with all other time points $(P<0.001)$, and it was lower than prepartum at wk 5 and $7(P<0.001$; Figure 4$)$. No BCS effects were observed on 3-MH concentration, despite numerically greater values in low-BCS cows (Table 5 ).

Plasma creatinine was analyzed at wk -4, 1, 2, and 7. Overall, creatinine concentration decreased from
$71.0 \mu M$ at wk -4 to $56.9 \mu M$ at wk $7(P<0.001$; Figure 4), and tended to be lower for low- compared with medium- and high-BCS cows (contrast: $P=$ 0.10; Table 5; Figure 4). Cows in second lactation had greater creatinine concentration than cows in thirdand-greater lactation, and a parity by week interaction existed (Table 5) because differences disappeared after the first week postpartum (data not shown). The ratio of 3-MH:creatinine increased at wk 1 and 2 relative to wk 4 and $7(P<0.001)$, and was greater for low-BCS 


\begin{tabular}{|c|c|c|c|c|c|c|c|c|c|c|c|c|}
\hline \multirow[b]{2}{*}{ Item } & \multicolumn{2}{|c|}{ Parity $^{1}$} & \multicolumn{3}{|c|}{ BCS group } & \multirow[b]{2}{*}{ SEM } & \multicolumn{6}{|c|}{$P$-value } \\
\hline & 2 & $3+$ & High & Medium & Low & & Parity & BCS group & Time & $\begin{array}{l}\text { Parity } \\
\times \text { time }\end{array}$ & $\begin{array}{l}\text { BCS group } \\
\times \text { time }\end{array}$ & $\begin{array}{l}\text { Contrast low vs. } \\
\text { medium }+ \text { high }\end{array}$ \\
\hline $\mathrm{NEFA}^{2}(\mu M)$ & 353 & 389 & $500^{\mathrm{a}}$ & $349^{\mathrm{b}}$ & $264^{\mathrm{b}}$ & 38 & $<0.01$ & $<0.01$ & $<0.001$ & NS & $<0.05$ & - \\
\hline $\mathrm{BHBA}^{2}(\mathrm{~m} M)$ & 0.75 & 0.99 & $1.10^{\mathrm{a}, \mathrm{x}}$ & $0.74^{\mathrm{b}}$ & $0.76^{\mathrm{ab}, \mathrm{y}}$ & 0.11 & $<0.05$ & $<0.05$ & $<0.0001$ & $<0.05$ & $<0.01$ & - \\
\hline Glucose $^{2}(\mathrm{mg} / \mathrm{dL})$ & 61.7 & 59.6 & 61.3 & 61.4 & 59.3 & 1.2 & NS & NS & $<0.001$ & $<0.001$ & NS & - \\
\hline $3-\mathrm{MH}^{2,3}(\mu M)$ & 5.67 & 5.13 & 5.00 & 5.36 & 5.85 & 0.51 & NS & NS & $<0.001$ & NS & NS & NS \\
\hline Creatinine $^{4}(\mu M)$ & 74.5 & 59.8 & 69.4 & 70.8 & 61.2 & 4.4 & $<0.01$ & NS & $<0.01$ & $<0.01$ & NS & 0.10 \\
\hline $3-\mathrm{MH} /$ creatinine $^{4}$ & 0.089 & 0.103 & 0.088 & 0.088 & 0.111 & 0.011 & NS & $<0.10$ & $<0.001$ & NS & NS & $<0.05$ \\
\hline Insulin $^{2}(\mu \mathrm{IU} / \mathrm{mL})$ & 15.4 & 15.1 & 15.9 & 15.0 & 14.8 & 0.77 & NS & NS & $<0.001$ & $<0.05$ & NS & - \\
\hline IGF-1 $^{2}(\mathrm{ng} / \mathrm{mL})$ & 96.7 & 71.8 & $98.2^{\mathrm{a}}$ & $77.0^{\mathrm{b}}$ & $77.6^{\mathrm{b}}$ & 6.2 & $<0.01$ & $<0.05$ & $<0.001$ & 0.001 & $<0.001$ & - \\
\hline $\operatorname{Leptin}^{2}(\mathrm{ng} / \mathrm{mL})$ & 2.07 & 2.30 & 2.62 & 1.96 & 1.96 & $0.28-0.46$ & NS & NS & $<0.001$ & NS & $<0.001$ & - \\
\hline
\end{tabular}

a,b Means within a row with different superscript letters differ $(P<0.05)$.

${ }^{\mathrm{x}, \mathrm{y}}$ Means within a row with different superscript letters tend to differ $(P=0.07)$.

${ }^{1}$ Parity during the current lactation.

${ }^{2}$ Samples collected at wk $-4,-2,1,2,3,5$, and 7 relative to calving.

${ }^{3} 3$ - $\mathrm{MH}=3$-methylhistidine.

${ }^{4}$ Samples collected at wk $-4,1,2$, and 7 relative to calving.
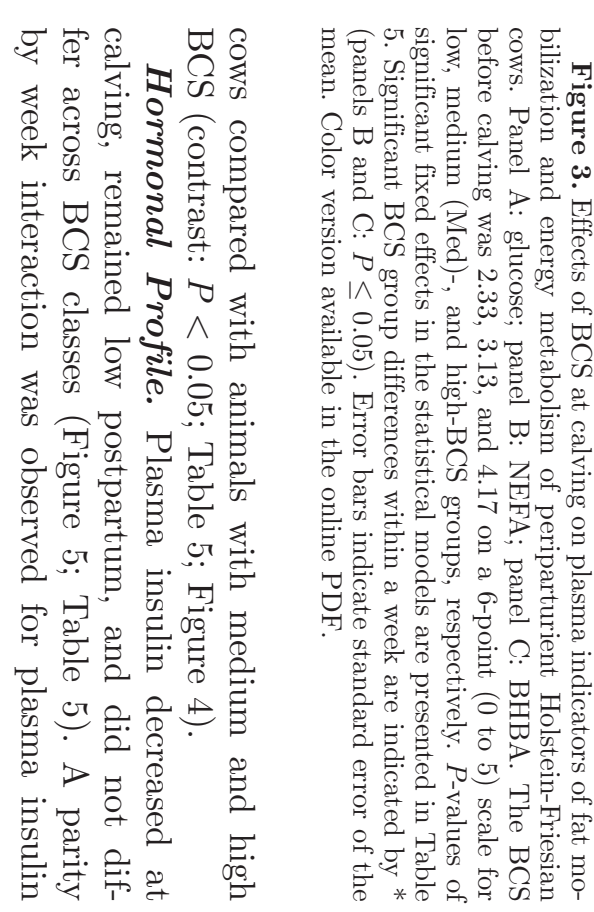

BHBA $(\mathrm{m} M)$

$\Omega$

NEFA $(\mu M)$

$\infty$

Glucose $(\mathrm{mg} / \mathrm{dL}) \quad \supset \stackrel{m}{\longrightarrow}$

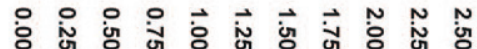
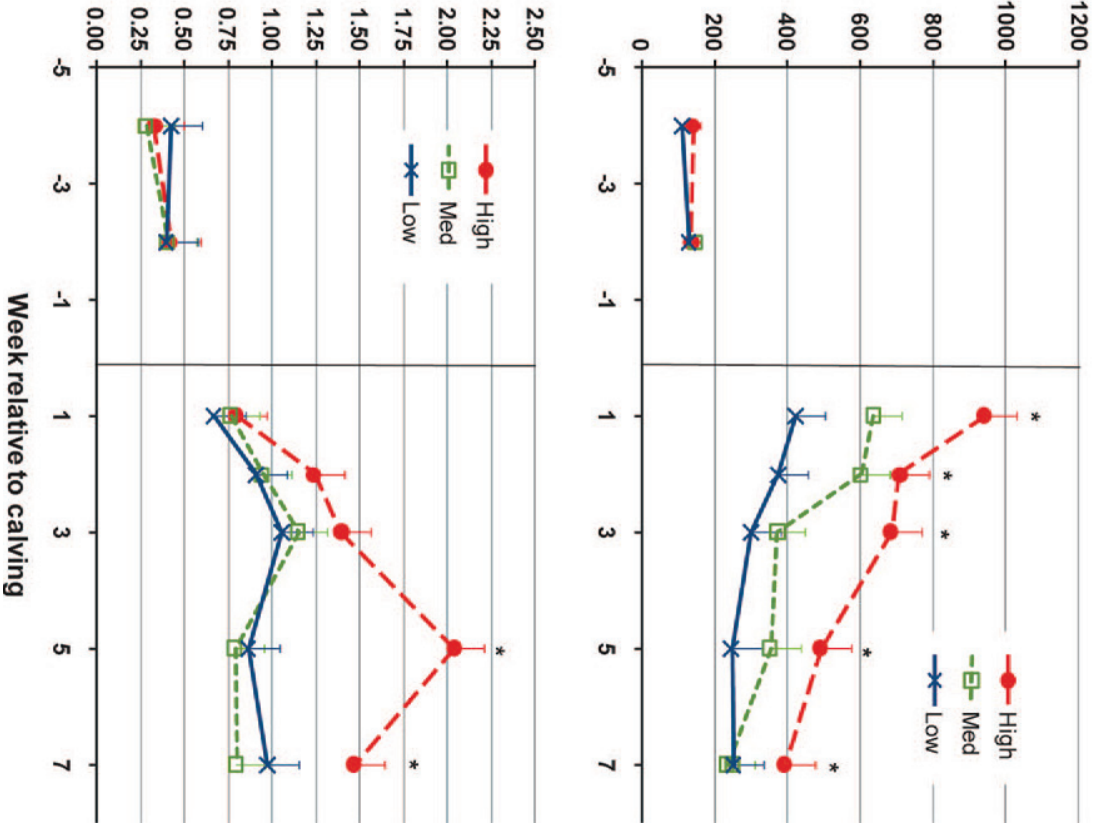

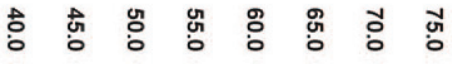

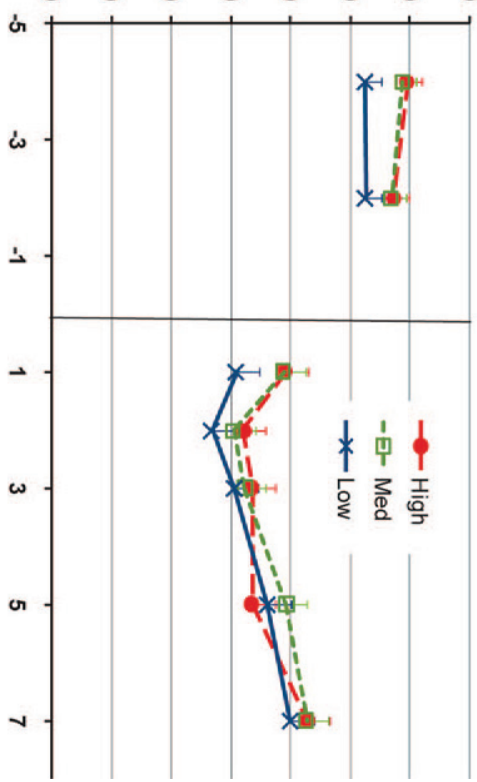


A

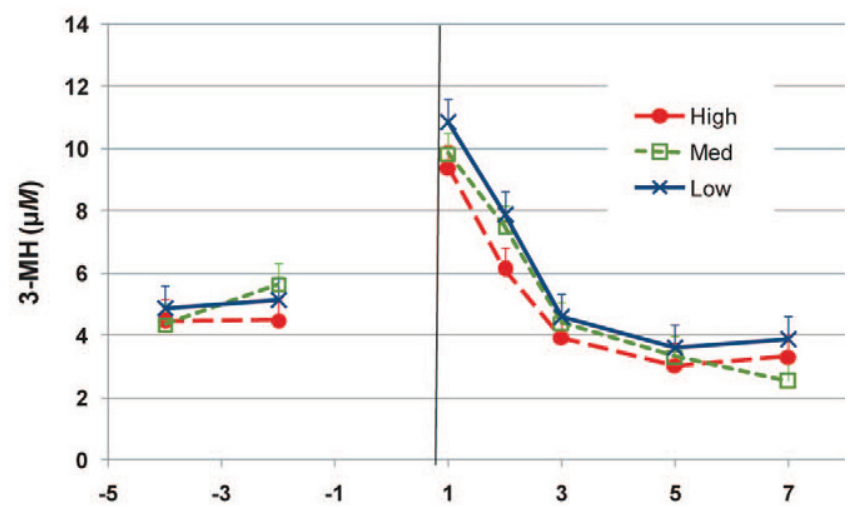

B
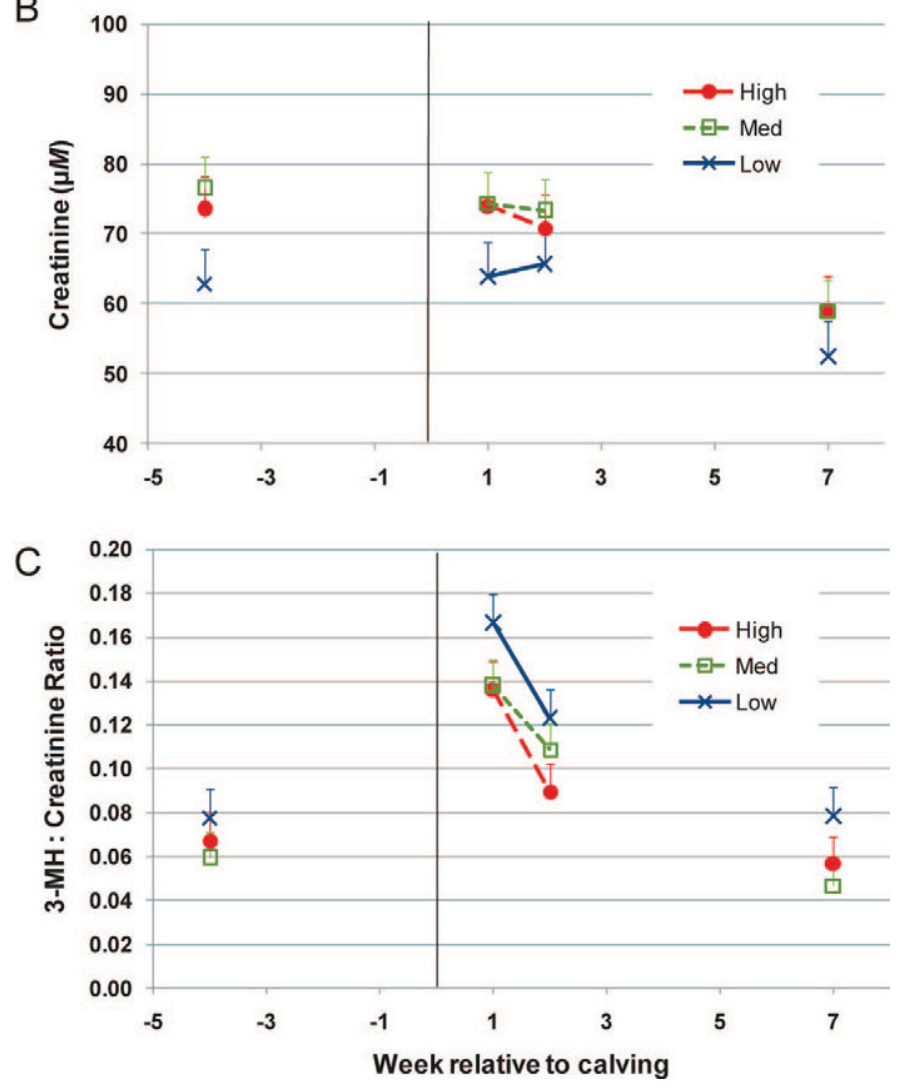

Figure 4. Effects of BCS at calving on plasma indicators of muscle mobilization of periparturient Holstein-Friesian cows. Panel A: 3-methylhistidine (3-MH); panel B: creatinine; panel C: 3-MH:creatinine ratio. The BCS before calving was $2.33,3.13$, and 4.17 on a 6 -point ( 0 to 5) scale for low-, medium (Med)-, and high-BCS groups, respectively. $P$-values of significant fixed effects in the statistical models are presented in Table 5. Contrasts of low versus Med and high BCS: panel B: $P=0.10$; panel C: $P<0.05$. Error bars indicate standard error of the mean. Color version available in the online PDF.

concentration $(P<0.05)$ because insulin concentration was greater for second- compared with third-and-greater-lactation cows during the second week of lactation (14.7 vs. $11.9 \mu \mathrm{IU} / \mathrm{mL} ; P<0.01$; data not shown).

Plasma IGF-1 concentrations were greatest for the high-BCS group throughout the study $(P<0.05$; Table
5; Figure 5). At wk -4, IGF-1 concentration was 208, 156 , and $150 \pm 14 \mathrm{ng} / \mathrm{mL}$ for high-, medium-, and low-BCS cows $(P<0.001)$, respectively. Plasma IGF-1 concentrations decreased sharply postpartum and then increased gradually during the first $7 \mathrm{wk}$ of lactation $(P<0.001$; Figure 5). Postpartum IGF-1 concentration was 64,50 , and $45 \pm 6.4 \mathrm{ng} / \mathrm{mL}$ for high-, medium-, and low-BCS cows $(P<0.05)$, respectively. A parity effect and parity by time interaction were observed on IGF-1 concentration, which was greater for secondthan third-and-greater lactation cows (Table 5), with significant differences postpartum (data not shown).

Prepartum plasma leptin concentration was greatest in the high-BCS group and did not differ between medium- and low-BCS classes $(P<0.05$; Figure 5$)$. A significant correlation existed between prepartum BCS and plasma leptin concentration in wk $-2(P<$ $\left.0.001 ; \mathrm{R}^{2}=0.31\right)$, but leptin variance was greater in the high-BCS group (Levene's test: $P<0.05$ ) due to 3 high values in overconditioned cows (data not shown). Leptin concentrations decreased sharply at calving for all BCS groups, and postpartum levels remained lower than prepartum throughout the first 7 wk of lactation $(P \leq 0.05)$. No effect of BCS group was observed on postpartum leptin concentration (Table 5; Figure 5).

\section{Milk FA Composition and Secretion}

Milk FA composition and secretion of selected FA are presented in Table 6 and Figure 6. There was a significant time effect for milk content of all FA studied except cis-9 16:1. Milk fat concentration of most major FA (i.e., content $\geq 2 \%$ ) was affected by calving BCS, except for 18:0, 6:0, 4:0, $\Sigma$ trans FA, and Ltrans 18:1. Cows calving with low BCS had greater milk content of 10:0, 12:0, 14:0, 15:0, 16:0, 20:0, 20:3n-6, 22:0, $\Sigma$ SFA, $\Sigma$ odd- and branched-chain FA (OBCFA), and $\Sigma$ 10:0 to 15:0 than the high-BCS group, whereas cows calving with high BCS had greater milk content of cis-9 18:1, $\Sigma$ cis 18:1, cis-9,cis-12 18:2, cis-9,trans-11 conjugated linoleic acid, cis-11 20:1, $\Sigma$ MUFA, and $\Sigma$ PUFA. No statistical differences existed between highand medium-BCS groups for most FA. The exceptions were 15:0, cis-9 16:1, 18:3n-3, cis-9 20:1, 20:3n-6, and $\mathrm{OBCFA}$. The medium-BCS group had the greatest concentrations of 18:3n-3 and cis-9 20:1 of all 3 BCS classes. Only the concentration of 15:0 differed across the 3 calving BCS groups. Secretion of milk cis-9 18:1, cis-9,cis-12 18:2, and 18:3n-3 was lowest for cows calving with low BCS, and did not differ between the highand medium-BCS groups. No BCS class effects were observed on secretion of milk medium-chain FA in milk fat (Table 6). 

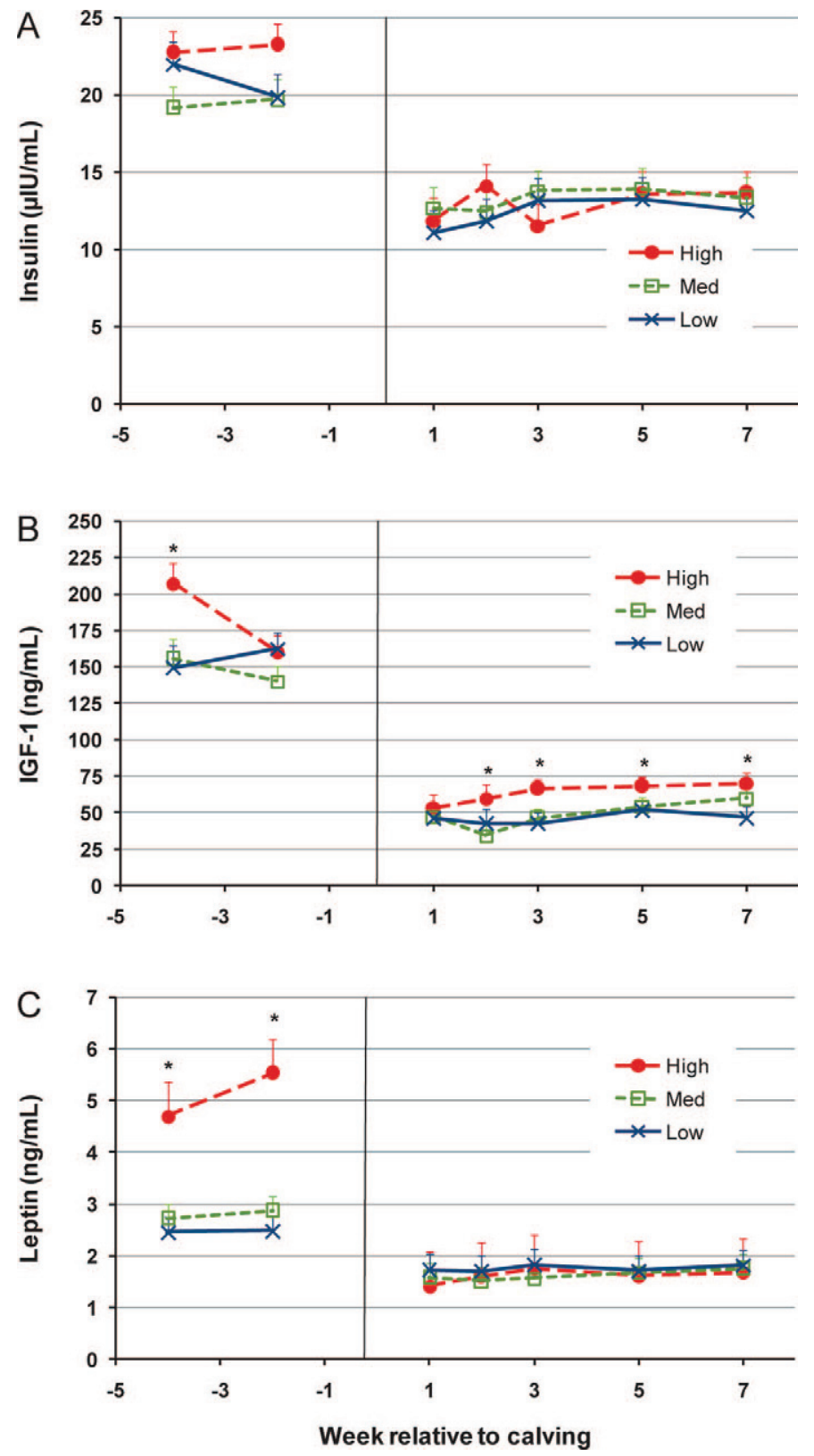

Figure 5. Effects of BCS at calving on plasma concentrations of insulin (A), IGF-1 (B), and leptin (C) in periparturient Holstein-Friesian cows. The BCS before calving was 2.33, 3.13, and 4.17 on a 6 -point (0 to 5) scale for low-, medium (Med)-, and high-BCS groups, respectively. $P$-values of significant fixed effects in the statistical models are presented in Table 5. Significant BCS group differences within a week are indicated by ${ }^{*}$ (panels B and C: $P<0.05$ ). Error bars indicate standard error of the mean. Color version available in the online PDF.

Cows in second lactation had greater concentrations of milk 6:0, 8:0, 10:0, cis-9 10:1, 12:0, 14:0, 15:0, trans-11 18:1, $\Sigma$ trans $18: 1$, cis- 9 , trans- 11 , cis-15 conjugated linolenic acid, 20:0, cis-9 20:1, 22:0, 22:5n-3 (+ 26:0), 24:0, $\Sigma$ SFA, $\Sigma$ OBCFA, $\Sigma$ trans FA, and $\Sigma$ 10:0 to 15:0, than cows in third-and-greater lactation. And the latter had greater concentrations of cis-9 18:1, $\Sigma$ cis 18:1, 18:3n-3, and $\Sigma$ MUFA. No parity effects were observed on milk 16:0 concentration. Cows in third-and-greater lactation had greater secretion of milk 16:0, 17:0, 18:0, cis-9 18:1, cis-9,cis-12 18:2, and 18:3n-3 than cows in second lactation. No parity effects were observed on secretion of $\mathrm{C} 10$ to $\mathrm{C} 15 \mathrm{FA}$.

\section{DISCUSSION}

\section{BCS, Dairy Performance, and EBAL}

Semi-mountain dairy production systems in the Auvergne region of France are traditionally grass-based and calvings are concentrated in the fall and winter seasons. Cows may undergo extended lactations, and individual differences in calving interval contribute to promote herd BCS heterogeneity. This variability has to be managed, and a need exists to better understand the dynamics of body reserve mobilization. In the present study, the BCS differences at calving were interrelated with the duration of previous calving interval. The BCS before calving was $2.33,3.13$, and 4.17 on a 6 -point $(0$ to 5) scale for low-, medium-, and high-BCS groups, respectively, and the average calving interval among the 3 BCS groups ranged from 362 to $640 \mathrm{~d}$ (Table 1).

Despite the differences in calving BCS, postpartum BCS loss did not differ among groups. Body condition scoring was not sensitive enough to detect differences in body reserve mobilization during early lactation. This may be due to the use of internal fat reserves, and the relatively short duration of the study. The literature shows a positive relationship between calving BCS and BCS loss postpartum, and the number of days to reach the nadir of BCS (Broster and Broster, 1998; Roche et al., 2009). The lack of differences in BCS loss in this study could be explained because it lasted only until 7 wk, whereas the nadir of BCS in fatter cows may occur after $12 \mathrm{wk}$ postpartum (Broster and Broster, 1998). When BCS loss is expressed as percentage of prepartum BCS, low-, medium-, and high-BCS groups lost respectively 53,47 , and $33 \%$ of BCS by wk 7 , further suggesting that high-BCS cows were still mobilizing body fat at the end of the study. Body weight was lowest for low-BCS cows but it did not differ between medium- and high-BCS cows, which may be due to differences in body size or body composition between cows in medium- and high-BCS groups, which were not measured.

Cows with medium BCS tended to have greater postpartum DMI than low- and high-BCS groups. Some studies showed a negative association between calving BCS and postpartum DMI, but this is not always the case (Broster and Broster, 1998; Roche et al., 2009). Deleterious effects of high BCS on DMI may not be de- 
Table 6. Effects of BCS at calving and parity on milk FA composition ${ }^{1}$ and secretion ${ }^{2}$ of early-lactation Holstein-Friesian cows

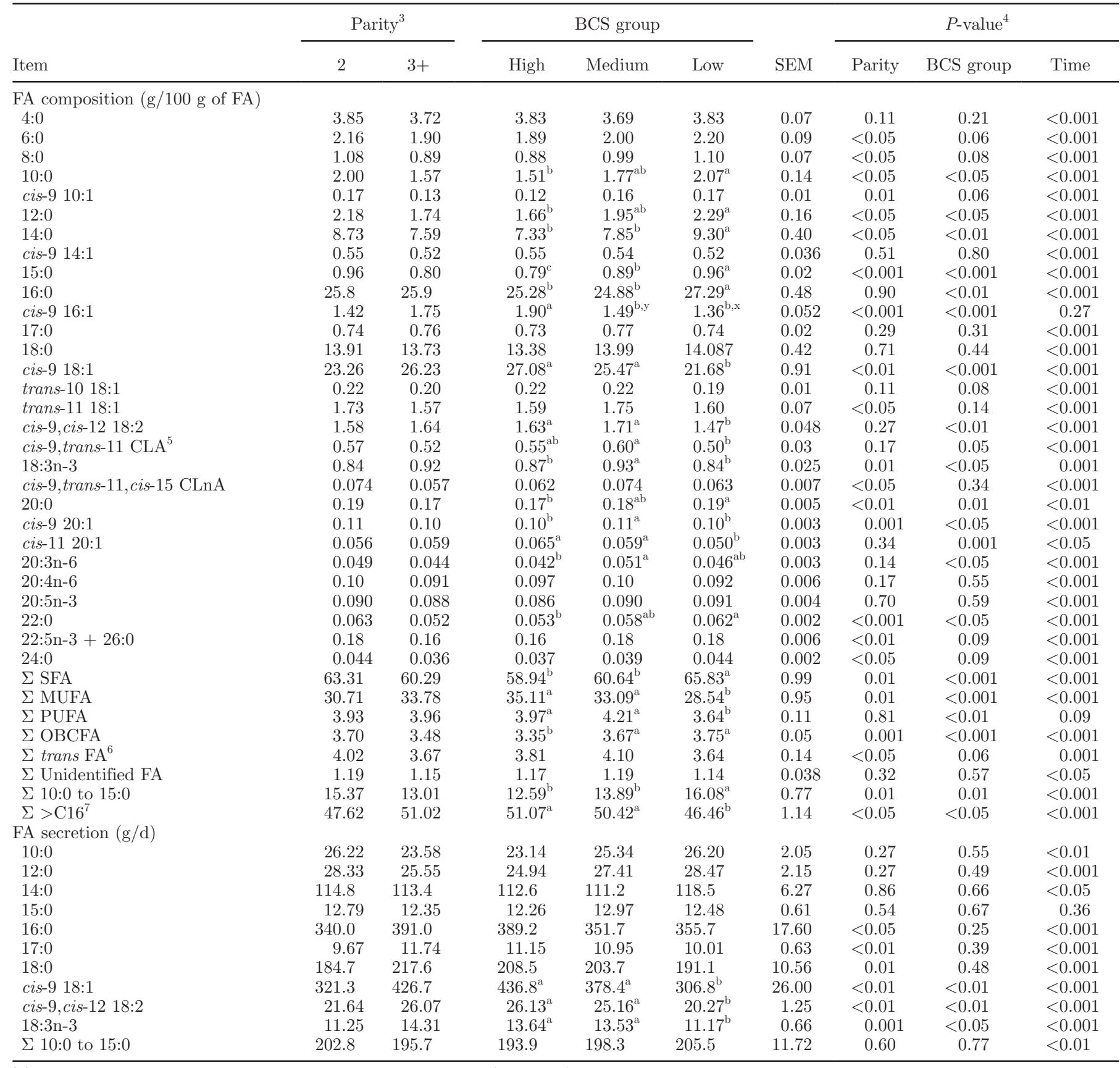

${ }^{\mathrm{a}-\mathrm{c}}$ Means within a row with different superscript letters differ $(P<0.05)$.

${ }^{\mathrm{x}, \mathrm{y}}$ Means within a row with different superscript letters tend to differ $(P=0.06)$.

${ }^{1}$ Weeks 1 to 7 postpartum.

${ }^{2}$ Weeks 2 to 7 postpartum.

${ }^{3}$ Parity during the current lactation.

${ }^{4}$ Parity by time interaction was nonsignificant for all variables except for concentration of cis-9 14:1, trans-11 18:1, cis-9,trans-1,cis-15 conjugated linolenic acid $(\mathrm{CLnA}), 20: 3 \mathrm{n}-6$ and 20:5n-3 $(P<0.05)$; BCS group by time interaction was nonsignificant for all variables except for concentration of cis-9 10:1, cis-9 14:1, 15:0, and $\Sigma$ odd- and branched-chain FA (OBCFA; $P \leq 0.05$ ).

${ }^{5}$ Contained trans-7, cis-9 and trans-8,cis-10 conjugated linoleic acid (CLA) as minor components.

${ }^{6}$ Sum of FA containing at least 1 trans double bond.

${ }^{7}$ Sum of FA with more than 16 carbons. 
A
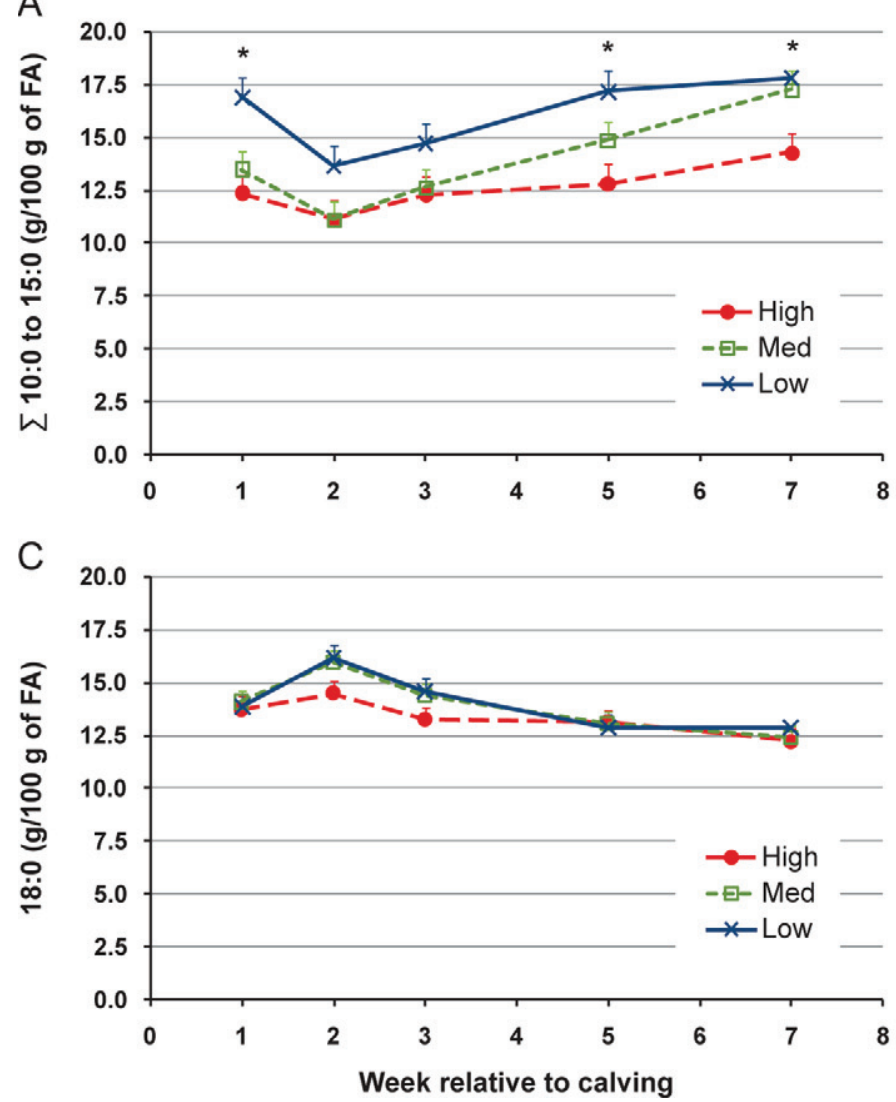

B

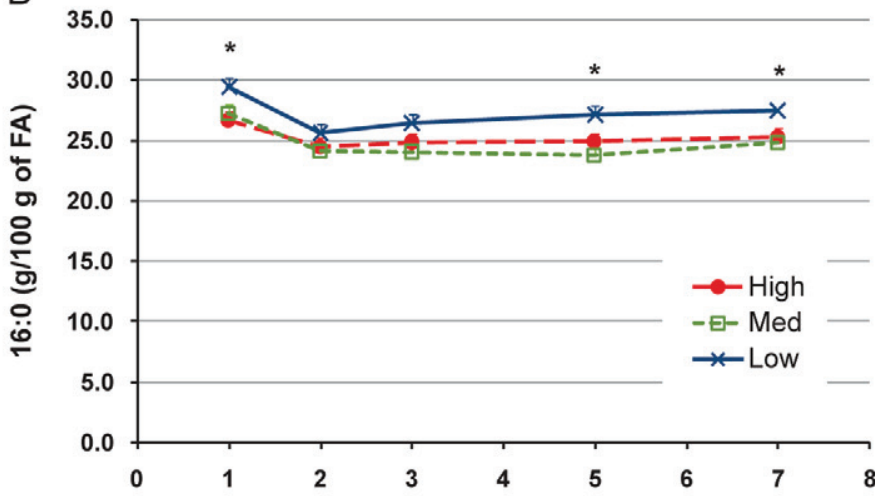

D

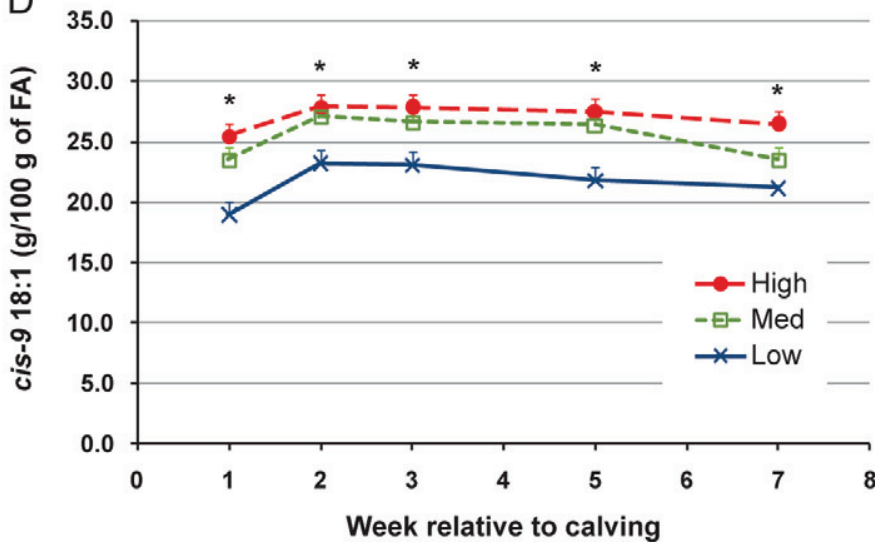

Figure 6. Effects of BCS at calving on composition of selected milk FA in early-lactation Holstein-Friesian cows. Milk samples were collected $4,11,18,32$, and $46 \pm 1 \mathrm{~d}$ relative to calving. The BCS before calving was $2.33,3.13$, and 4.17 on a 6 -point $(0$ to 5$)$ scale for low-, medium (Med)-, and high-BCS groups, respectively. $P$-values of significant fixed effects in the statistical models are presented in Table 6 . Significant BCS group differences within a week are indicated by * (panels A and B: $P<0.05$; panel D: $P<0.01$ ). Error bars indicate standard error of the mean. Color version available in the online PDF.

tectable during the first weeks of lactation (Broster and Broster, 1998). Additionally, the BCS effects on DMI may result from pre- and postpartum diets and their interactions. In the present study, the lactation TMR contained only $30 \%$ concentrate and $6.1 \mathrm{MJ}$ of $\mathrm{NE}_{\mathrm{L}} / \mathrm{kg}$ of DM (Table 1). Low-energy diets may affect the ability of lean cows to compensate for the limited availability of body fat via increased DMI, due to physical constraints imposed by bulkier feedstuffs (Garnsworthy and Jones, 1987; Chilliard, 1992). Because all cows in this study received the same diets, interactions between pre- and postpartum diets on postpartum DMI are not likely. Nonetheless, we cannot exclude that the relatively short duration of the study postpartum may have precluded the detection of eventual BCS effects on DMI.

The literature shows a curvilinear relationship between BCS at calving and milk production (Broster and Broster, 1998; Roche et al., 2009). In the current study, only numerical effects of BCS class were observed on milk yield during the first 7 wk of lactation, with lean cows producing $3 \mathrm{~kg} / \mathrm{d}$ less than the medium-BCS group, and the latter producing $1.2 \mathrm{~kg} / \mathrm{d}$ more than the high-BCS group. Cows with high BCS at calving produced milk with greater fat content than lean cows, reflecting the availability of body fat in the former. Enhanced mobilization of preformed FA in fatter cows is confirmed by plasma NEFA concentrations and milk FA profile and secretion, which is in agreement with the literature (Garnsworthy and Topps, 1982). Accordingly, cows in the high-BCS group had the lowest EBAL. Conversely, low-BCS cows had the lowest plasma NEFA concentrations during the first 2 wk of lactation and the lowest milk protein yield of the 3 BCS classes. Under low-energy diets, lean cows reduce milk and component yield to a greater extent than cows calving with moderate BCS, because lean animals have limited ability to rely on body reserves to sustain lactation (Chilliard, 1992). 


\section{Plasma Indicators of Adipose and Muscle Mobilization}

A sharp increase in plasma NEFA concentration is common at calving (Doreau, 1983; Reid et al., 1986; Vazquez-Añon et al., 1994). It is concomitant with accumulation of triglycerides in the liver, which remain elevated during the first weeks postpartum and may alter hepatic function and lead to the onset of metabolic disorders (Vazquez-Añon et al., 1994). Overconditioning of dairy cows enhances plasma NEFA and liver triglyceride accumulation (Rayssiguier et al., 1986; Reid et al., 1986). Furthermore, liver triglyceride infiltration is aggravated by feeding a low-energy diet postpartum (Rayssiguier et al., 1986). In the present study, cows calving with high BCS had the greatest plasma NEFA and BHBA concentrations postpartum, but did not perform better than medium-BCS cows for milk and protein yield. In North-American conventional dairy systems, multiparous cows with plasma NEFA concentrations greater than $800 \mu M$ during wk 1 or 2 postpartum have 2 to 4 times greater risk of culling within first 60 DIM for cows (Roberts et al., 2012). In the current study, cows calving with high BCS had plasma NEFA concentrations above this threshold, and plasma BHBA concentrations were greater than $1.2 \mathrm{~m} M$ after wk 1 postpartum, which indicates subclinical ketosis (Roberts et al., 2012).

Cows calving with medium BCS presented diverse production and metabolic profiles. They were closer to high- or low-BCS groups, depending on the variable studied. In some cases, such as for plasma NEFA concentration, the relationship changed over time because medium-BCS cows did not differ statistically from the high-BCS group during the first weeks after calving, but decreased to levels similar to low-BCS cows as lactation progressed. This diversity of responses found in the medium-BCS group probably reflects the diversity of individual adaptations during early lactation (Hammon et al., 2009). Furthermore, a potential confounding effect of frame size differences among groups cannot be excluded because BW did not differ between mediumand high-BCS cows, and could explain numerical effects on DMI and milk yield.

The amino acid $3-\mathrm{MH}$ is a product of actin and myosin degradation that is not reused for protein synthesis. Urinary excretion of 3-MH around calving is an indicator of protein mobilization in early lactation (Chibisa et al., 2008). Because creatinine excretion is proportional to body muscle mass, the urinary $3-\mathrm{MH}$ :creatinine ratio may standardize muscle protein mobilization for total muscle mass (Simmons et al., 1994). Total urine collection is not feasible in most trials involving periparturient cows; therefore, plasma $3-\mathrm{MH}$ concentration has been used as an indicator of muscle catabolism (Blum et al., 1985) and may discriminate cows receiving diets low in protein content during the periparturient period (Doepel et al., 2002). In the current experiment, plasma $3-\mathrm{MH}$ presented the typical profile of the periparturient period and concentrations were within the ranges found by others (Bell and Bauman, 1997; Doepel et al., 2002). Plasma 3-MH was significantly increased in wk 1 and 2, corresponding to samples collected on 4 and $11 \pm 1$ DIM, respectively. Therefore, the period of intense muscle protein mobilization was short, which is in agreement with previous estimates of protein mobilization postpartum (Komaragiri and Erdman, 1997; Chilliard, 1999; Chibisa et al., 2008). Plasma 3 -MH concentrations on wk 5 and 7 were lower than prepartum $(P<0.001)$, as found in previous studies (Kokkonen et al., 2005), probably due to decreasing muscle mass during the first weeks of lactation. A numerically greater $3-\mathrm{MH}$ concentration was observed in low-BCS cows, but interanimal variation of periparturient 3-MH profiles precluded the detection of statistical differences among BCS classes. Nonetheless, the uterus dry weight change during involution was estimated to be less than $2.5 \mathrm{~kg}$, which may lead to a moderate contribution for plasma $3-\mathrm{MH}$ in the dairy cow that may mobilize from near zero to $24 \mathrm{~kg}$ of protein during early lactation, as previously discussed (Plaizier et al., 2000). Furthermore, because $3-\mathrm{MH}$ is studied during the periparturient period for all cows, an eventual bias due to uterine involution would not affect the validity of group comparisons.

Plasma creatinine and the $3-\mathrm{MH}$ :creatinine ratio was studied to assess and control for putative differences in muscle mass among BCS classes, because BCS may account for differences of muscle mass in addition to adiposity (Reid et al., 1986; Kokkonen et al., 2005). Creatinine was analyzed at wk $-4,1,2$, and 7 , which corresponded to baseline, intense mobilization, and postmobilization periods based on 3-MH data. Creatinine concentration at wk 7 of lactation was lower than prepartum (56.9 vs. $71.0 \mu M ; P<0.001)$. Previous studies showed a decrease in creatinine concentrations concomitant with a reduction in longissimus dorsi diameter during the periparturient period (Bruckmaier et al., 1998; Kokkonen et al., 2005). The decrease in plasma creatinine concentration during early lactation could be partially explained by altered kidney function, because plasma creatinine concentration is a function of muscle mass and kidney glomerular filtration rate (Perrone et al., 1992). Nonetheless, a study involving 6 cows at wk $-4,2$, and 7 relative to calving showed no changes in filtration rate, despite increased urine volume at wk 7 (Maltz and Silanikove, 1996). Low-BCS cows probably had less muscle mass because plasma creatinine 
concentration tended to be lower than in medium- and high-BCS groups $(P=0.10$; Table 5$)$, which is in agreement with previous observations of positive correlations between BCS and indicators of body muscle content, such as area of muscle fibers (Reid et al., 1986) and diameter of the longissimus dorsi muscle (Kokkonen et al., 2005). The greater 3-MH:creatinine ratio observed in low-BCS cows indicates that lean cows experienced more intense mobilization of muscle protein at the onset of lactation, compared with animals with medium and high BCS $(P<0.05$; Table 5$)$, despite the trend for lower muscle mass, as indicated by plasma creatinine concentration. Previous research showed that cows that are underfed postpartum lose more body protein during the first 4 wk of lactation than cows allowed ad libitum intake (6.3 vs. $1 \mathrm{~kg}$ ), and that the effect of undernutrition on protein mobilization is enhanced in higher-yielding animals, which mobilized $12.5 \mathrm{~kg}$ of body protein (Chilliard and Robelin, 1983). Therefore, the extent of protein mobilization during early lactation is influenced by environmental factors and interacts with the genetic background. In the current experiment, where all animals received the same diet, results suggest that low-BCS cows relied to a greater extent on mobilized muscle protein during the first weeks of lactation compared with animals that calved with more adipose reserves. The mechanisms regulating peripartum protein mobilization are not well characterized but may be mediated by changes in plasma insulin, growth hormone (GH), and IGF-1 concentrations (Bell et al., 2000), and upregulated expression of components of proteolytic pathways in the muscle (Chibisa et al., 2008). Nonetheless, because BCS differences among groups derive, at least in part, from differences in the duration of the previous intercalving interval due to extended lactations and dry periods, potential confounding factors cannot be excluded, and these results should be confirmed under a controlled experimental setting.

\section{Hormonal Profile}

Plasma insulin and glucose followed patterns typical of the periparturient period, with a sharp decrease postpartum and sustained low concentrations during early lactation, reflecting the shortfall of glucogenic nutrients, negative EBAL, and preferential partitioning of nutrients toward milk production (Chilliard, 1992; Bell and Bauman, 1997). No effects of BCS group were observed on plasma insulin and glucose concentrations, probably because DMI did not differ, and all cows received identical diets. Insulin concentration may not be a good indicator of EBAL during early lactation because it does not discriminate among cows with different BCS, EBAL, plasma NEFA concentration, and degree of liver triglyceride accumulation during the periparturient period (Hammon et al., 2009).

Plasma IGF-1 concentrations decreased postpartum probably due to the uncoupling of the GH:IGF-1 axis. During the periparturient period, GH induction of hepatic IGF-1 production is impaired because low insulin concentrations downregulate the expression of GH receptor in the liver (Lucy et al., 2001). Plasma IGF-1 concentrations were greatest for the high-BCS group, which was unexpected because this group experienced the lowest EBAL due to greater milk fat yield. The IGF-1 concentrations contrast with previous studies where grazing cows calving with BCS $\geq 3$ ( 1 to 5 scale) had greater prepartum IGF-1 concentration than cows with lower BCS, but did not differ postpartum (Meikle et al., 2004). Complex relationships existed among postpartum IGF-1 concentration, BCS, EBAL, and week of lactation in the current study. Postpartum IGF-1 was negatively correlated with plasma NEFA and BHBA concentrations, and absolute value of BCS loss $(P<$ $0.001 ;-0.31 \leq \mathrm{r} \leq-0.28 ; \mathrm{n}=138)$, and positively correlated with week of lactation, postpartum BCS, DMI, EBAL, and glucose concentration $(P<0.05 ; 0.18 \leq \mathrm{r}$ $\leq 0.35 ; 110 \leq \mathrm{n} \leq 136$; data not shown). These results are in agreement with other studies reporting negative correlations of IGF-1 with NEFA and BHBA concentrations (Vandehaar et al., 1999; Meikle et al., 2004; Wathes et al., 2007), and positive correlations between BCS and IGF-1 concentration in multiparous cows during wk 4 and 7 postpartum (Wathes et al., 2007). A putative effect of BCS on postpartum plasma IGF-1 concentration deserves further investigation because it may be associated with the declining fertility that has been observed in the Holstein breed.

In the current experiment, the high-BCS group had the greatest plasma leptin concentration prepartum, which can be explained only by differences in adiposity, because EBAL and insulin concentration did not differ prepartum across BCS groups. Therefore, the effects of high BCS on prepartum leptin concentrations are in agreement with the concept that adiposity is the major determinant of leptinemia in nonlactating ruminants (Chilliard et al., 2005). Others have found positive correlations between BCS and leptin 1 wk before calving in multiparous cows (Wathes et al., 2007), during the periparturient period of primiparous cows (Meikle et al., 2004) and in late lactation (Ehrhardt et al., 2000). Leptin concentrations decreased sharply postpartum and remained lower than prepartum for all BCS groups throughout the first $7 \mathrm{wk}$ of lactation. No BCS effects were observed on postpartum leptin concentration, as previously observed (Holtenius et al., 2003). One study reported a positive correlation between postpartum BCS and plasma leptin, but only in fatter cows (BCS 
at calving $\geq 3$ ) and during the first 2 wk of lactation (Meikle et al., 2004). The decrease in leptin concentration at calving is associated to the changes in EBAL that occur during this period, and may be mediated by decreased insulin concentrations and impaired insulinmediated glucose utilization (Block et al., 2003; Chilliard et al., 2005), and enhanced $\beta$-adrenergic stimulation (Chilliard et al., 2001), which are all typical of the periparturient period.

\section{Milk FA Composition and Secretion}

Week of lactation, EBAL, and BCS at calving were the main factors influencing milk FA composition in the present study because all animals received the same diet. Short- and medium-chain FA are mainly synthesized de novo by the epithelial cells of the mammary gland, and part of 16:0 and longer-chain FA are preformed and derived from blood circulation, and may originate directly from the diet or ruminal metabolism, or be mobilized from fat depots (Chilliard et al., 2000b). In the present experiment, milk fat content of $\Sigma$ 10:0 to 15:0 increased and 18:0 and cis-9 18:1 decreased as lactation progressed, as previously reported (Gross et al., 2011). Nonetheless, FA composition of samples collected during the first week (corresponding to $4 \pm 1$ DIM) suggest a lesser contribution of preformed FA compared with samples from the second week of lactation (Figure 6). A similar time pattern was previously reported for FA composition of colostrum (Santschi et al., 2009).

Cows calving with low BCS had greater milk content of medium-chain FA (e.g., $\Sigma$ 10:0 to 15:0 and 16:0), and lower content and secretion of cis-9 18:1 compared with medium- and high-BCS groups. This was probably due to limited availability of body fat in lean cows, in agreement with their lowest plasma NEFA concentrations during early lactation. The main FA circulating in the nonesterified fraction in ruminants are 18:1 (45\%), 16:0 $(30 \%)$, and 18:0 (15\%; Scalia et al., 2006), which reflects the composition of bovine fat. Decreased content in medium-chain FA during early lactation may be due to lower availability of precursor substrates arising from DMI, to inhibition of FA synthesis in the mammary gland by C18 FA, or result from a dilution effect by increased flow of preformed FA (Chilliard et al., 2000b). Because the intensity of lipolysis postpartum depends, at least in part, on the degree of body fatness (Chilliard et al., 2000a), the effects of BCS on milk fat secretion and FA composition are likely due to the lower body fat content and mobilization in lean cows.

No statistical differences existed between high- and medium-BCS groups for the milk content and secretion of most FA. This may be explained by the lack of differences in plasma NEFA concentration during the first $5 \mathrm{wk}$ of lactation, despite the lower EBAL in the high-BCS group.

\section{Parity Effects}

All cows in this study were multiparous; nonetheless, parity was controlled in the statistical analyses because second-lactation cows have not reached their mature body size and production potential. Calving interval, calving BCS, BW, and BCS loss were greater for thirdand-greater- compared with second-lactation cows. A trend existed for greater milk production and significantly greater milk fat content and yield for third-andgreater-lactation cows, leading to lower EBAL, greater plasma NEFA and BHBA concentrations, lower IGF-1 concentration, and a trend for lower glucose concentration postpartum in third-and-greater-lactation cows. The milk fat content of preformed FA such as 18:1 was greater and the content of short- and medium-chain FA was lower in third-and-greater- compared with secondlactation cows, which is in agreement with differences in calving BCS (3.7 vs. 2.9 points), and metabolic, hormonal, and production profiles, indicating enhanced use of mobilized body fat in fatter and older cows.

\section{CONCLUSIONS}

Cows calving with high BCS presented elevated plasma NEFA and BHBA concentrations. Unexpectedly, high-BCS cows also had the greatest concentrations of IGF-1 despite their lowest EBAL postpartum. Low-BCS cows produced less milk fat than the highBCS group, and had the lowest milk protein yield of the 3 BCS groups. Overall, metabolite data show that lean cows mobilized less body fat during the first weeks of lactation, but may have experienced more intense muscle protein catabolism, as indicated by their greatest plasma 3-MH:creatinine ratio. These results support the initial hypothesis that lean cows have limited availability of body reserves and may rely to a greater extent on body protein to meet nutritional needs of early lactation, compared with animals with higher BCS associated with extended lactations. Low body reserve status during early lactation decreased the productivity of dairy cows fed a conventional winter diet based on preserved grass, in practical conditions of a semi-mountain dairy system. Because the calving BCS of cows in this study was related to previous intercalving intervals, confounding factors not controlled by the experimental design cannot be excluded. Therefore, these results should be confirmed using an experimental approach where calving BCS variation would be controlled by design. 


\section{ACKNOWLEDGMENTS}

The authors thank M. Barbet, N. Bioret, and the staff at the experimental unit Monts d'Auvergne of Orcival (INRA, UE1296, Puy-de-Dôme, France) for animal care and sample collection; D. Bany, E. Tixier, and M. Tourret (INRA, UMR 1213, Saint-Genès-Champanelle, France) for laboratory analyses; N. Hafnaoui and D. Remond (INRA, UMR 1019, Saint-Genès-Champanelle, France) for the quantification plasma 3-MH; and S. Lerch (INRA, UMR 1213) for insightful discussions on milk FA profiles. This research was funded by the Department of Animal Physiology and Livestock Production Systems (PHASE; Nouzilly, France) of INRA.

\section{REFERENCES}

Adechian, S., M. Balage, D. Remond, C. Migné, A. Quignard-Boulangé, A. Marset-Baglieri, S. Rousset, Y. Boirie, C. Gaudichon, D. Dardevet, and L. Mosoni. 2012. Protein feeding pattern, casein feeding, or milk-soluble protein feeding did not change the evolution of body composition during a short-term weight loss program. Am. J. Physiol. Endocrinol. Metab. 303:E973-E982.

Bazin, S., P. Augeard, M. Carteau, H. Champion, Y. Chilliard, G. Cuylle, C. Disenhaus, G. Durand, R. Espinasse, A. Gascoin, M. Godineau, D. Jouanne, O. Ollivier, and B. Remond. 1984. Grille de notation de l'état d'engraissement des vaches pie-noires. Inst. Tech. l'Elevage Bovin, Paris, France.

Bell, A. W., and D. E. Bauman. 1997. Adaptations of glucose metabolism during pregnancy and lactation. J. Mammary Gland Biol. Neoplasia 2:265-278.

Bell, A. W., W. S. Burhans, and T. R. Overton. 2000. Protein nutrition in late pregnancy, maternal protein reserves and lactation performance in dairy cows. Proc. Nutr. Soc. 59:119-126.

Block, S. S. R. P. Rhoads, D. E. Bauman, R. A. Ehrhardt, M. A. McGuire, B. A. Crooker, J. M. Griinari, T. R. Mackle, W. J. Weber, M. E. Van Amburgh, and Y. R. Boisclair. 2003. Demonstration of a role for insulin in the regulation of leptin in lactating dairy cows. J. Dairy Sci. 86:3508-3515.

Blum, J. W., T. Reding, F. Jans, M. Wanner, M. Zemp, and K. Bachmann. 1985. Variations of 3-methylhistidine in blood of dairycows. J. Dairy Sci. 68:2580-2587.

Broster, W. H., and V. J. Broster. 1998. Body score of dairy cows. J. Dairy Res. 65:155-173.

Bruckmaier, R. M., L. Gregoretti, F. Jans, D. Faissler, and J. W. Blum. 1998. Longissimus dorsi muscle diameter, backfat thickness, body condition scores and skinfold values related to metabolic and endocrine traits in lactating dairy cows fed crystalline fat or free fatty acids. Zentralbl. Veterinärmed. A 45:397-410.

Chagas, L. M., J. J. Bass, D. Blache, C. R. Burke, J. K. Kay, D. R. Lindsay, M. C. Lucy, G. B. Martin, S. Meier, F. M. Rhodes, J. R. Roche, W. W. Thatcher, and R. Webb. 2007. Invited review: New perspectives on the roles of nutrition and metabolic priorities in the subfertility of high-producing dairy cows. J. Dairy Sci. 90:4022-4032.

Chibisa, G. E., G. N. Gozho, A. G. Van Kessel, A. A. Olkowski, and T. Mutsvangwa. 2008. Effects of peripartum propylene glycol supplementation on nitrogen metabolism, body composition, and gene expression for the major protein degradation pathways in skeletal muscle in dairy cows. J. Dairy Sci. 91:3512-3527.

Chilliard, Y. 1992. Physiological constraints to milk production: Factors which determine nutrient partitioning, lactation persistency, and mobilization of body reserves. World Rev. Anim. Prod. 27:19-26.

Chilliard, Y. 1999. Metabolic adaptations and nutrient partitioning in the lactating animal. Pages 503-552 in Biology of Lactation. J.
Martinet, L. M. Houdebine, and H. H. Head, ed. INRA Éditions, Paris, France.

Chilliard, Y., M. Bonnet, C. Delavaud, Y. Faulconnier, C. Leroux, J. Djiane, and F. Bocquier. 2001. Leptin in ruminants. Gene expression in adipose tissue and mammary gland, and regulation of plasma concentration. Domest. Anim. Endocrinol. 21:271-295.

Chilliard, Y., C. Delavaud, and M. Bonnet. 2005. Leptin expression in ruminants: Nutritional and physiological regulations in relation with energy metabolism. Domest. Anim. Endocrinol. 29:3-22.

Chilliard, Y., A. Ferlay, Y. Faulconnier, M. Bonnet, J. Rouel, and F. Bocquier. 2000a. Adipose tissue metabolism and its role in adaptations to undernutrition in ruminants. Proc. Nutr. Soc. 59:127134.

Chilliard, Y., A. Ferlay, R. M. Mansbridge, and M. Doreau. 2000b. Ruminant milk fat plasticity: Nutritional control of saturated, polyunsaturated, trans and conjugated fatty acids. Ann. Zootech. 49:181-205.

Chilliard, Y., and J. Robelin. 1983. Mobilization of body proteins by early lactating cows measured by slaughter and $\mathrm{D}_{2} \mathrm{O}$ techniques. Pages 195-198 in IVth Int. Symp. Protein Metabolism and Nutrition. Vol. 2. EAAP Publication no. 31. European Federation of Animal Science (EAAP), Rome Italy.

Delavaud, C., A. Ferlay, Y. Faulconnier, F. Bocquier, G. Kann, and Y. Chilliard. 2002. Plasma leptin concentration in adult cattle: Effects of breed, adiposity, feeding level, and meal intake. J. Anim. Sci. 80:1317-1328

Doepel, L., H. Lapierre, and J. J. Kennelly. 2002. Peripartum performance and metabolism of dairy cows in response to prepartum energy and protein intake. J. Dairy Sci. 85:2315-2334.

Doepel, L., G. E. Lobley, J. F. Bernier, P. Dubreuil, and H. Lapierre. 2009. Differences in splanchnic metabolism between late gestation and early lactation dairy cows. J. Dairy Sci. 92:3233-3243.

Doreau, M. 1983. Influence de la prise alimentaire sur les variations de différents constituants plasmatiques chez la vache en fin de gestation et en début de lactation. Ann. Rech. Vet. 14:39-48.

Edmonson, A. J., I. J. Lean, L. D. Weaver, T. Farver, and G. Webster 1989. A body condition scoring chart for Holstein dairy cows. J. Dairy Sci. 72:68-78.

Ehrhardt, R. A., R. M. Slepetis, J. Siegal-Willott, M. E. Van Amburgh, A. W. Bell, and Y. R. Boisclair. 2000. Development of a specific radioimmunoassay to measure physiological changes of circulating leptin in cattle and sheep. J. Endocrinol. 166:519-528.

Garnsworthy, P. C., and G. P. Jones. 1987. The influence of body condition at calving and dietary-protein supply on voluntary food intake and performance in dairy cows. Anim. Prod. 44:347-353.

Garnsworthy, P. C., and J. H. Topps. 1982. The effects of body condition of dairy cows at calving, food intake and performance in early lactation on blood composition of dairy cows given complete diets. Anim. Prod. 35:121-135.

Glasser, F., M. Doreau, A. Ferlay, and Y. Chilliard. 2007. Technical note: Estimation of milk fatty acid yield from milk fat data. J Dairy Sci. 90:2302-2304.

Gross, J., H. A. van Dorland, R. M. Bruckmaier, and F. J. Schwarz. 2011. Milk fatty acid profile related to energy balance in dairy cows. J. Dairy Res. 78:479-488.

Hammon, H. M., G. Stürmer, F. Schneider, A. Tuchscherer, H. Blum, T. Engelhard, A. Genzel, R. Staufenbiel, and W. Kanitz. 2009. Performance and metabolic and endocrine changes with emphasis on glucose metabolism in high-yielding dairy cows with high and low fat content in liver after calving. J. Dairy Sci. 92:1554-1566.

Holtenius, K., S. Agenäs, C. Delavaud, and Y. Chilliard. 2003. Effects of feeding intensity during the dry period. 2. Metabolic and hormonal responses. J. Dairy Sci. 86:883-891.

INRA (Institut National de la Recherche Agronomique). 2007. Alimentation des bovins, ovins et caprins. Besoins des animaux-Valeur des aliments. Editions Quae Versailles, France.

Kay, J. K., C. V. C. Phyn, J. R. Roche, and E. S. Kolver. 2009. Extending lactation in pasture-based dairy cows. II: Effect of genetic strain and diet on plasma hormone and metabolite concentrations. J. Dairy Sci. 92:3704-3713. 
Kokkonen, T., J. Taponen, T. Anttila, L. Syrjälä-Qvist, C. Delavaud, Y. Chilliard, M. Tuori, and A. T. Tesfa. 2005. Effect of body fatness and glucogenic supplement on lipid and protein mobilization and plasma leptin in dairy cows. J. Dairy Sci. 88:1127-1141.

Kolver, E. S., J. R. Roche, C. R. Burke, J. K. Kay, and P. W. Aspin. 2007. Extending lactation in pasture-based dairy cows: I. Genotype and diet effect on milk and reproduction. J. Dairy Sci. 90:5518-5530.

Komaragiri, M. V., and R. A. Erdman. 1997. Factors affecting body tissue mobilization in early lactation dairy cows. 1. Effect of dietary protein on mobilization of body fat and protein. J. Dairy Sci. 80:929-937.

Lerch, S., A. Ferlay, D. Pomiès, B. Martin, J. A. A. Pires, and Y. Chilliard. 2012a. Rapeseed or linseed supplements in grass-based diets: Effects on dairy performance of Holstein cows over 2 consecutive lactations. J. Dairy Sci. 95:1956-1970.

Lerch, S., A. Ferlay, K. J. Shingfield, B. Martin, D. Pomiès, and Y. Chilliard. 2012b. Rapeseed or linseed supplements in grass-based diets: Effects on milk fatty acid composition of Holstein cows over two consecutive lactations. J. Dairy Sci. 95:5221-5241.

Lucy, M. C., H. Jiang, and Y. Kobayashi. 2001. Changes in the somatotrophic axis associated with the initiation of lactation. J. Dairy Sci. 84(E. Suppl.):E113-E119.

Maltz, E., and N. Silanikove. 1996. Kidney function and nitrogen balance of high yielding dairy cows at the onset of lactation. J. Dairy Sci. $79: 1621-1626$.

Meikle, A., M. Kulcsar, Y. Chilliard, H. Febel, C. Delavaud, D. Cavestany, and P. Chilibroste. 2004. Effects of parity and body condition at parturition on endocrine and reproductive parameters of the cow. Reproduction 127:727-737.

Perrone, R. D., N. E. Madias, and A. S. Levey. 1992. Serum creatinine as an index of renal function: New insights into old concepts. Clin. Chem. 38:1933-1953.

Plaizier, J. C., J. P. Walton, A. Martin, T. Duffield, R. Bagg, P. Dick, and B. W. McBride. 2000. Short communication: Effects of monensin on 3-methylhistidine excretion in transition dairy cows. J. Dairy Sci. 83:2810-2812.

Rayssiguier, Y., A. Mazur, B. Rémond, Y. Chilliard, and E. Gueux. 1986. Influence de l'état corporel au vêlage et du niveau d'alimentation en début de lactation sur la stéatose hépatique chez la vache laitière. Reprod. Nutr. Dev. 26:359-360.

Reid, I. M., C. J. Roberts, R. J. Treacher, and L. A. Williams. 1986. Effect of body condition at calving on tissue mobilization, development of fatty liver and blood chemistry of dairy cows. Anim. Prod. 43:7-15.

Roberts, T., N. Chapinal, S. J. LeBlanc, D. F. Kelton, J. Dubuc, and T. F. Duffield. 2012. Metabolic parameters in transition cows as indicators for early-lactation culling risk. J. Dairy Sci. 95:30573063.

Roche, J. R., N. C. Friggens, J. K. Kay, M. W. Fisher, K. J. Stafford, and D. P. Berry. 2009. Invited review: Body condition score and its association with dairy cow productivity, health, and welfare. J. Dairy Sci. 92:5769-5801.

Santschi, D. E., H.-R. Wettstein, F. Leiber, A.-K. M. Witschi, and M. Kreuzer. 2009. Colostrum and milk fatty acids of dairy cows as influenced by extruded linseed supplementation during the transition period. Can. J. Anim. Sci. 89:383-392.

Scalia, D., N. Lacetera, U. Bernabucci, K. Demeyere, L. Duchateau, and C. Burvenich. 2006. In vitro effects of nonesterified fatty acids on bovine neutrophils oxidative burst and viability. J. Dairy Sci. $89: 147-154$.

Simmons, C. R., W. G. Bergen, M. J. Vandehaar, D. J. Sprecher, C. J. Sniffen, E. P. Stanisiewski, and H. A. Tucker. 1994. Protein and fat metabolism in cows given somavubove before parturition. J. Dairy Sci. 77:1835-1847.

Vandehaar, M. J., G. Yousif, B. K. Sharma, T. H. Herdt, R. S. Emery, M. S. Allen, and J. S. Liesman. 1999. Effect of energy and protein density of prepartum diets on fat and protein metabolism of dairy cattle in the periparturient period. J. Dairy Sci. 82:1282-1295.

Vazquez-Añon, M., S. Bertics, M. Luck, R. R. Grummer, and J. Pinheiro. 1994. Peripartum liver triglyceride and plasma metabolites in dairy cows. J. Dairy Sci. 77:1521-1528.

Wathes, D. C., Z. Cheng, N. Bourne, V. J. Taylor, M. P. Coffey, and S. Brotherstone. 2007. Differences between primiparous and multiparous dairy cows in the inter-relationships between metabolic traits, milk yield and body condition score in the periparturient period. Domest. Anim. Endocrinol. 33:203-225. 